\title{
Electra e Orestes: reconhecimento e espaço na tragédia grega
}

\author{
Márcia Cristina Lacerda Ribeiro*
}

\begin{abstract}
RIBEIRO, M.C.L. Electra e Orestes: reconhecimento e espaço na tragédia grega.
\end{abstract}
Revista do Museu de Arqueologia e Etnologia, São Paulo, 20: 251-276, 2010.

Resumo: Este texto objetiva, inicialmente, levantar alguns aspectos sobre o reconhecimento (anagnórisis) entre Electra e Orestes à luz da Poética de Aristóteles; num segundo momento, refletir sobre o espaço construido onde se passam tais cenas. A cena de reconhecimento entre Electra e Orestes é-nos proporcionada pelos três trágicos cujas peças chegaram completas até nós: Ésquilo (Coéforas), Sófocles (Electra) e a tragédia homônima de Euripides (Electra).

Palavras-chave: Cenas de reconhecimento - Espaço - Tragédia grega Electra.

\section{Introdução}

$\mathrm{N}$ este trabalho pretendemos, inicialmente, levantar alguns aspectos sobre o reconhecimento (anagnórisis) entre Electra e Orestes à luz da Poética de Aristóteles; num segundo momento, refletir sobre o espaço construido onde se passam tais cenas. A cena de reconhecimento entre Electra e Orestes énos proporcionada pelos três trágicos cujas peças chegaram completas até nós: Ésquilo (Coéforas, 458 a.C.), Sófocles (Electra, 415 a.C.) e Euripides (Electra, 415 a.C.). ${ }^{1}$ Trata-se do único exemplo nas tragédias sobreviventes em que é possivel cotejar o mesmo Mito (mythos) sob três olhares diferentes. Ele representa parte da história dos Atridas, familia que inspirou os poetas, como assegura Aristóteles em duas passagens:

\section{[...] outrora se serviam os poetas de} qualquer Mito; agora, as melhores Tragédias versam sobre poucas familias, como sejam as de Alcmeôn, Édipo, Orestes, Meleagro, Tiestes e Télefo e quaisquer outros que obraram ou padeceram tremendas coisas (Poética XIII, 1453a 20).

[...] não há muitas famílias de cujas histórias se possa tirar argumento de Tragédias: quando buscavam situações $\left(^{*}\right)$ Universidade do Estado da Bahia (UNEB); Mestranda em História Econômica (FFLCH/USP); Bolsista CNPq. <marciaribeiro400@hotmail.com>

(1) A tradução da Poética utilizada é a de Eudoro de Souza. São Paulo: Ars Poética, 1993. A tradução de Coéforas é de Manuel de Oliveira Pulquério: Oresteia (Agamenon, Coéforas, Eumênides). Lisboa: Edições Setenta, 2008. As traduções de Sófocles e Euripides são de Trajano Vieira,
Sófocles/Eurípides. Electra(s), São Paulo: Ateliê Editorial, 2009; as exceções serão devidamente referenciadas. O autor, entretanto, não dispõe os números dos versos em sua obra; optamos, então, por incluir o número da página onde se encontra a passagem transcrita ao lado dos versos correspondentes ao texto grego, este disponivel no site do Perseus, http://www.perseus.tufts.edu/hopper/ 
trágicas, os poetas as encontraram, não por arte, mas por fortuna, nos Mitos tradicionais, não tendo mais que acomodá-los a seus propósitos; eis porque se constrangeram a recorrer à história das famílias que semelhantes calamidades sucederam (Poét. XIV, 1454a 10).

Contudo, em que pese se tratar de um único Mito, somos brindados com três histórias diferentes, como bem frisou Aristóteles: "não é necessário seguir à risca os Mitos tradicionais donde são extraidas as nossas Tragédias; pois seria ridicula fidelidade tal, quando é certo que ainda as coisas conhecidas são conhecidas de poucos, e contudo agradam elas a todos igualmente" (Poét. IX, 1451b 25). Continuando, Aristóteles complementa: "se por um lado o poeta pode usar da liberdade para transitar pelo Mito, por outro, não deve fazer alterações drásticas nos Mitos tradicionais, como, por exemplo, mudar o destino de Clitemnestra e ela não ser assassinada pelo seu filho" (Poét. XIV, 1453b 25).

Depois de enumerar as seis partes constitutivas da Tragédia (Mito, Caráter, Elocução, Pensamento, Espetáculo e Melopéia) (Poét. VI, 1449b 25-35), Aristóteles divide os Mitos em simples e complexo: o primeiro efetua a mutação de fortuna sem peripécia ou reconhecimento (Poét. X, 1452a 10-15); e o segundo, que nos interessa mais de perto, pois nele se encaixam as peças por nós analisadas, opera a mudança pelo reconhecimento, pela peripécia ou pelos dois conjuntamente (Poét. Idem). O Mito complexo, por sua vez, é constituido por três partes: a peripécia (peripetéia), o reconhecimento (anagnórisis) e a catástrofe (páthos). O reconhecimento é definido pelo pensador: "Como indica o próprio significado da palavra, é a passagem do ignorar ao conhecer, que se faz para amizade ou inimizade das personagens que estão destinadas para a dita ou para a desdita" (Poét. XI, 1452a 30). Para Elizabeth Belfiore, o reconhecimento para philia (philian) envolve o começo de uma relação de bons serviços para a pessoa reconhecida. "[Ele] deve resultar em uma ação que muda a direção da peça e contribui para o seu movimento continuo" (Belfiore 1992: 158). ${ }^{2}$ Se não muda a direção dos acontecimentos, pelo menos os facilita. É o caso da peça de Sófocles: Orestes chegou a Argos com os planos de vingança traçados, mas eles foram facilitados pelo auxílio de Electra.

O Reconhecimento, prossegue Aristóteles, se dá entre pessoas; pode acontecer de uma pessoa em relação a outra ou entre duas pessoas, como ocorre em nossas peças: Orestes reconhece Electra primeiro e, em seguida, é por ela reconhecido; é o Reconhecimento duplo. Em Ésquilo e Sófocles, Orestes reconhece Electra e depois lhe revela a sua identidade. Em Euripides, o herói também a reconhece, mas a sua identidade é revelada pelo velho amigo da familia, que o encaminhou ao exílio, quando ele era ainda pequeno, a pedido de Electra.

Aristóteles classifica as várias espécies de reconhecimento (Poét. XVI, 1454b 20-1455a 20). Segundo a sua avaliação, duas das nossas tragédias, a Electra de Sófocles e a Electra de Euripides, enquadram-se nos tipos mais frequentes e menos artísticos. São os reconhecimentos feitos através de sinais congênitos ou adquiridos, como a cicatriz no supercílio de Orestes, descoberta pelo velho pedagogo de Agamenão, em Euripides, e o anel que Orestes apresenta à Electra sofocliana. As Coéforas, pelo contrário, gozam do prestigio do pensador; para ele, o reconhecimento se efetua por um silogismo, e é por isso o seu segundo em preferência, perdendo apenas para aqueles que resultam da própria intriga, por dispensarem meios artificiais, como os sinais. Voltaremos a essa discussão posteriormente.

Feitas essas considerações, passemos à noção de espaço construído sobre o qual pretendemos refletir. $\mathrm{O}$ conceito vem sendo utilizado nos estudos sobre a cidade antiga, desenvolvidos pelo Laboratório de Estudos da

(2) Tomamos da autora o sentido de philia: "uma relação formal, com direitos e obrigações especificas, especialmente entre parentes" (Belfiore 1992: 158). Salvo indicação em contrário, todas as traduções são de nossa autoria. 
Cidade Antiga - LABECA. ${ }^{3}$ Elaborado pelo arquiteto moderno Amós Rapoport, que defende que o principal conceito de espaço está vinculado a uma análise antropológica, relacionada ao "ambiente construido", é uma noção abstrata indicada para descrever os produtos da atividade construtiva humana. Em sentido amplo, reporta-se a qualquer alteração física no ambiente natural, perpetrada pelas mãos do homem. Assim, são ambientes construidos: edificios, moradias, templos, túmulos, lugares de reunião, santuários, locais afastados das casas; incluem espaços não necessariamente fechados, como uma praça, uma rua, um marco territorial, como as hermas de Atenas. Comportam ainda elementos específicos, como portas, paredes, pisos, dentre outros (Rapoport 1978: 17 e Lawrence e Low 1990: 453-505).

O ambiente construido é tanto um produto social como cultural. Para Amós Rapoport (1982: cap. 3), as construções são resultados da necessidade sócio-cultural e abarcam funções sociais, religiosas, politicas e culturais. Sua forma não é determinada apenas por fatores físicos, o clima ou a topografia, mas pelas ideias da sociedade, suas formas de economia e organização social, e pelos valores que ela estabelece a cada período.

O ambiente construido molda o comportamento das pessoas que interagem com ele e contém informações simbólicas que se transmitem de maneira não-verbal e que se pode "ler". "O meio-ambiente pode limitar o comportamento e orientá-lo" (Rapoport 1978: 286).

(3) O LABECA - Laboratório de Estudos da Cidade Antiga, fundado em 2006, é coordenado pela professora Maria Beatriz Borba Florenzano, e "tem por objetivo aprofundar e difundir estudos sobre a sociedade grega através da análise do espaço na cidade antiga. Sediado no Museu de Arqueologia e Etnologia da USP (MAE/USP), o LABECA está vinculado ao projeto temático 'Cidade e Território na Grécia antiga: organização do espaço e sociedade', financiado pela FAPESP" (Disponivel em http://www.mae.usp.br/labeca, acessado em abril de 2009). A pesquisa de mestrado que estamos desenvolvendo está ligada a esse Laboratório, é orientada pela professora supra mencionada e se intitula "A Cidade Antiga na Tragédia Grega: entre o Espaço Construido e o Espaço Concebido".
Como acentua H. L. Moore, "O espaço é um texto que pode ser lido" (apud Lawrence e Low 1990: 453-505). É nesse sentido que pretendemos refletir sobre o espaço trágico nas cenas de reconhecimento: o túmulo de Agamenão, em Ésquilo; a frente do palácio dos Atridas, em Sófocles; e a frente da casa de Electra, nos confins da Argólida, em Euripides.

Irène Chalkia reflete sobre a noção de espaço e as suas implicações para o estudo da obra de Eurípides e entendemos que os seus comentários também sejam válidos para as obras de Ésquilo e Sófocles, se não esquecermos, é claro, que os poetas trabalham o espaço de forma diferente.

A noção de espaço, se difícil de definir, recobre a um só tempo o real e o imaginário, o visivel e o invisivel, tudo o que está cenicamente presente ou simplesmente evocado pelos personagens. É na manifestação dessas oposições e sua expressão no texto ou na cena, que o estudo do espaço encontra sua justificação: permite revelar os códigos de comunicação entre o poeta e seu público. [...] O estudo do espaço pode tornar inteligivel a nós o quadro de referências - históricas, sócioculturais ou outras - que era comum ao poeta e ao seu público, quando da composição e da representação das peças (Chalkia 1986: 9).

É importante sublinhar que Aristóteles não se ocupou da questão do espaço em seu tratado sobre a tragédia. Para Irène Chalkia, o espaço está ligado ao ato da representação, que não acontecia da mesma forma para os três trágicos e menos ainda na época de Aristóteles, quando as tragédias começavam a ser lidas, não só representadas (Chalkia 1986: 3).

De Agamenão, rei de Argos e comandante supremo da armada grega, diz J. Pierre Vernant (2002: 408): "de todos os reis, o mais rei é Agamêmnon: recebeu do próprio Zeus seu cetro de comando". O destemido e impetuoso guerreiro não se deteve mesmo quando imolou a própria filha - Ifigênia - para que ventos favoráveis conduzissem, de Áulis, a frota grega 
em direção às muralhas de Príamo. O herói passou dez anos ausente da sua cidade, combatendo valorosamente junto às torres de Tróia, até destruir toda a cidade, quando, então, retornou altivo, esperando receber da sua cidade e do seu palácio a celebração digna dos seus feitos e dos despojos conquistados. Porém, sendo tomado pela surpresa, o herói argivo tem a sua morte orquestrada pela esposa, Clitemnestra, e seu amante, Egisto. O seu filho varão, possivel vingador do hediondo crime - Orestes -, é enviado ao exílio por amigos, temendo que também ele fosse executado. Transcorridos os anos, o jovem retorna à Pátria com um único desejo: o de fazer justiça, reparando o crime cometido contra o seu pai.

Até aqui, os três poetas convergem no entendimento do Mito, mas, como acentuamos anteriormente, não faria nenhum sentido três pessoas escreverem exatamente o mesmo relato; dai advém a originalidade, a habilidade e a capacidade artística de cada tragediógrafo. Por isso, optamos por tratar separadamente as peças.

\section{Cenas de reconhecimento}

\subsection{Em Ésquilo}

N'As Coéforas, peça representada em 458 a.C., Orestes retorna do longo e forçado exilio à sua terra natal, dirige-se ao túmulo paterno, lamenta-se por não ter estado presente para chorar a morte de Agamenão e estender-lhe a mão (vv. 5-10). Nesse interim, um cortejo de mulheres avança em sua direção. Orestes e Pílade escondem-se e observam à distância. Orestes cogita sobre a possibilidade de Electra estar entre elas, sendo aquela que se distingue pela profunda tristeza (vv. 15-20). Imediatamente Orestes toma conhecimento do que se tratava: Clitemnestra havia enviado o cortejo para levar libações ao túmulo de Agamenão (vv. 20-25). Ouve do coro os seus lamentos com a triste sorte do palácio e de toda cidade, cujo povo estava tomado pelo temor: "o respeito invencivel, indomável, inatacável, que outrora penetrava os ouvidos e o espirito do povo, desapareceu, dando lugar ao temor" (vv. 55-60).
Entre os versos 85-90, Orestes ouve de Electra: "Que direi, ao derramar estas libações fúnebres? Como pronunciar palawras propícias? Que oração farei a meu pai? Tendemos a acreditar que a essa altura Orestes já confirmara a sua suspeita: tratava-se de Electra, embora ninguém tenha pronunciado o seu nome ou ela se revelado. Certamente não poderia se tratar de uma outra irmã, que sequer é mencionada na peça; mais do que ouvir o nome Electra, é através do seu discurso que ele a reconhece. Electra parece estar confusa, meio desorientada, sem saber como conduzir a libação, nem se ao menos deve fazê-la; pede conselho às amigas (o coro), solidárias no mesmo ódio (v. 100). Segue o diálogo entre o regente do Coro e a titubeante Electra:

Corifeu: É venerando o túmulo de teu pai como um altar que te vou dizer, visto que mo ordenas, o que tenho no coração.

Electra: Fala, animado como estás por esse sentimento de respeito que testemunhaste pelo túmulo de meu pai.

Corifeu: Faz as libações sobre o seu túmulo, pronunciando votos favoráveis àqueles que o amam.

Electra: Mas quais são as pessoas suas amigas que devo mencionar?

Corifeu: Primeiro, a ti própria, depois, a quem odeie Egisto.

Electra: Farei então estas orações por mim e por ti?

Corifeu: Pensa no que eu disse e conclui...

Electra: Que outra pessoa poderei eu associar ao nosso partido?

Corifeu: Lembra-te de Orestes, por longe que ele esteja.

Electra: Excelente idéia: não me podias ter aconselhado melhor.

Corifeu: Para os culpados, recordando-te do assassinio...

Electra: Que devo pedir? Guia-me na minha ignorância.

Corifeu: Pede que contra eles venha alguém, deus ou mortal...

Electra: Referes-te a um juiz ou a um vingador? 
Corifeu: Exprime-te sem rodeios: alguém que, por sua vez, os mate.

Electra: Não será impiedade dirigir aos deuses um pedido desses?

Corifeu: Porque há-de ser impio pagar o mal com o mal?

Nesse primeiro momento, Electra, embora cheia de ódio e insatisfação, não parece almejar qualquer vingança contra os assassinos do pai. Quando o coro the sugere que suplique aos deuses por alguém que os mate, ela se surpreende e indaga se não seria impio tal pedido. Ademais, é o coro quem lhe recorda que Orestes comunga dos mesmos ideais.

A ação do coro é fundamental para a transformação de Electra: da insegurança para a firmeza de propósito com que dirige as súplicas, bem de acordo com o que Aristóteles achava ideal: "o coro também deve ser considerado como um dos atores; deve fazer parte do todo, e da ação" (Poét. XVIII, 1456a 30).

Orestes continua ouvindo o lamento de Electra a clamar pelo seu retorno, quando esta vê sobre o túmulo um cacho de cabelos, o primeiro indício a preparar o reconhecimento, pois percebe a semelhança com os dela. O Corifeu pergunta se não seria de Orestes. Electra pensa que talvez o irmão pudesse ter enviado o cabelo em honra ao pai (v. 180). A heroina está profundamente emocionada, chora. Crê e descrê na possibilidade de o irmão ter enviado a oferenda. Fala como se o cacho de cabelo pudesse ser a resposta dos deuses à sua súplica: "Mas nós invocamos os deuses, que sabem que tempestades nos arrastam à maneira de marinheiros tomados por um turbilhão. E, se for de sua vontade que nós alcancemos a salvação, dum pequeno germe poderá sair um grande tronco" (vv. 200-205).

Para Solmsen, uma hipótese plausivel, embora alguns comentadores não tenham sugerido, é que, se uma pessoa reza fervorosamente por algo, ela espera e avalia a possibilidade de ser atendida. É o que possivelmente se passava na cabeça de Electra (Solmsen 1967: 32). Continua o autor:

Ainda uma paciente análise do que acontece nesse episódio mostra que, depois da oração fervorosa de Electra (vv. 124-151), suas condições emocionais tinham passado da crença que a oração tinha sido respondida, pelos estágios e graus de confiança diminuida, até que ela se encontrasse na tentadora incerteza expressada nas linhas (v. 200ss.) em que ela fala de si como marinheiros arrastados por uma tempestade (Solmsen 1967: 35).

Para Pietro Pucci, Solmsen falha ao não atentar para o significado religioso do cabelo no túmulo. "O reconhecimento do cabelo como pertencente a Orestes é, portanto, apenas uma evidência subsidiária e é apoiada pela evidência absoluta, o oferecimento do cabelo no túmulo e o significado religioso desse ato" (Pucci 1967: 367). O autor cita o texto "Droit et prédroit dans La Grèce ancienne" de L. Gernet, em que ele afirma que somente Orestes estaria apto a realizar esse ritual, pelo vínculo religioso entre o herdeiro homem e o pai morto. Conclui Gernet:

O reconhecimento, em Ésquilo, é apoiado pela consciência de Electra de que uma oferenda importante como um cacho de cabelo somente pode ser feita por um amigo e, consequentemente, depois das orações e do intenso clima religioso dos versos 124-163, somente por Orestes. O reconhecimento é confirmado pela similaridade do cabelo, enquanto que se abstrairmos a revelação da presença de um ofertante, nenhuma conclusão pode ser esboçada das pegadas apesar da similaridade do tamanho (Gernet 1949: 77, apud Pucci 1967: 367).

Acrescentemos a tudo isso um aspecto importante, mencionado na nossa introdução: o ambiente construido molda o comportamento das pessoas que interagem com ele, e ele é depositário de informações. Electra não está em qualquer lugar, está no túmulo, e não em qualquer túmulo, mas no do pai. E, por tudo que já falamos, é de se esperar que este fato tenha um forte impacto na forma como Electra reage. 
Electra, tomada de mistério e envolta por uma "auréola mágica", encontra o segundo indício: pegadas de duas pessoas junto ao túmulo, uma semelhante às dela, que imagina ser de Orestes, e a outra, de um companheiro (vv. 205-210). Ela está completamente desnorteada: "uma angústia me toma que a razão se perde" (v. 210).

Segundo Solmsen, as pegadas deveriam transmitir uma presunção mais forte do que o cacho de cabelo e reavivar as esperanças de Electra, mas ela está tão exausta pela provação de ansiedade e incerteza que já não pode projetar qualquer inferência mais distante, já não é capaz de uma conclusão racional (Solmsen 1967: 36). Na análise d'As Coéforas, Jacques Jouanna chama a atenção para a semelhança entre os pés de Electra e de Orestes. Para o autor, essa semelhança é um sinal de reconhecimento na epopeia homérica, Canto IV da Odisseia, vv. 149-150, quando Helena e Menelau notam a similitude entre Ulisses e Telêmaco, sobretudo pelos pés, mãos e cabelos; ou no Canto XIX da Odisseia, quando a ama reconhece Ulisses "pelos pés", pois é a cicatriz no pé o elemento decisivo para Euricléia reconhecer o seu senhor. Ésquilo, continua o autor, não estaria criando algo novo quando lança mão da semelhança entre cabelos e pés na cena que prepara o reconhecimento dos irmãos; "a forma dos pés era um indício pelo menos igual aos outros para discernir a semelhança física entre os membros de uma mesma familia" (Jouanna 1997: 78). Para ele, dificilmente se pode contestar que Ésquilo tenha na memória os poemas de Homero ao escrever a sua peça, de tal modo que o reconhecimento pelo formato dos membros, em vigor no período homérico, poderia ser válido também no periodo clássico.

É nesse clima - depois de Electra ver as pegadas - que ocorre a primeira etapa da cena de reconhecimento. Orestes se apresenta a Electra e afirma que a sua chegada é o resultado das súplicas intermitentes da irmã aos deuses: "Faz votos para que as preces que, no futuro, dirijas aos deuses obtenham os mesmos êxitos das de agora" (vv. 212-213).
Por um momento, Electra, que chegou a acreditar que os indícios representavam a presença do irmão, retrocede, pensa na possibilidade do engano, quer se certificar de que não se trata de um impostor a aproveitar-se da sua intensa fragilidade. Assistimos, assim, o que podemos chamar de segunda etapa do reconhecimento - a comprovação da identidade revelada. Orestes oferece à irmã o terceiro sinal, um tecido bordado por ela, e tenta convencê-la de ser o dono do cacho de cabelo encontrado sobre o túmulo: "... observa este anel de cabelo tão semelhante ao teu, aproximando-o do lugar onde ele foi cortado na cabeça do teu irmão. Vê este tecido, obra das tuas mãos; considera a cena de caça que o batente do tear nele traçou" (vv. 230-234). Electra, convencida, aceita a identidade do irmão, regozija-se, enche-se de esperança. Dá-se, assim, a terceira etapa do reconhecimento - a comemoração da nova identidade revelada.

Aristóteles, ao analisar as espécies de Reconhecimento, insere As Coéforas na quarta espécie, o silogismo, "pelo seguinte raciocínio: alguém chegou que me é semelhante, mas ninguém se me assemelha senão Orestes, logo quem veio foi Orestes (Poét. 1455a 5). Se o raciocínio de Electra fosse tão lógico, como quer ver Aristóteles, não seria necessário a comprovação da identidade; Orestes a convence ao aproximar o cacho de cabelo de onde foi recém cortado e ao apresentar um tecido em seu poder confeccionado pela irmã. E. Belfiore (1992: 155) registra que, para B. Perrin, no livro "Recognition Scenes in Greek Literature", publicado em 2009, "toda categoria envolve raciocinio e que o reconhecimento de Orestes por Electra n'As Coéforas (...) também envolve o uso de sinais".

N'As Coéforas, o reconhecimento ocorre de imediato, logo no primeiro episódio; a partir daí os crimes são traçados e Electra desaparece de cena para não mais retornar, não tendo, portanto, participação no seu desfecho.

\subsection{Em Sófocles}

Na Electra sofocliana, representada provavelmente em 415 a.C., mal desponta a manhã, Orestes já se encontra em terra natal ao lado de Pilade e do seu preceptor. Este lhe mostra os 
lugares que ainda criança foi obrigado a deixar, quando Electra o entregou aos seus cuidados: a floresta consagrada a Ínaco, a praça do deus Lupo, do lado oposto, o santuário de Hera e o palácio dos Atridas. Todo plano do assassinato já havia sido minuciosamente orquestrado, provavelmente antes da chegada a Argos e depois da consulta ao oráculo de Lóxias, quando Orestes tomou conhecimento de que ele próprio, usando apenas da astúcia, mataria os assassinos do pai.

A primeira etapa do plano consistia em o Preceptor levar ao palácio o relato da morte de Orestes, vitimado numa corrida de carros, enquanto o próprio Orestes visitava o túmulo paterno com oferendas, notadamente um cacho de cabelos. Em seguida, para completar o plano e torná-lo mais verossímil, Orestes e os seus companheiros levariam uma urna com as suas supostas cinzas ao palácio; tal artifício possibilitaria o seu ingresso no interior do palácio onde, finalmente, se daria o desfecho do plano.

Enquanto acertavam os últimos detalhes, o Preceptor e Orestes ouvem os prantos de alguém, vindos do interior do palácio. Orestes, tal qual n'As Coéforas (vv. 15-20), antevê a possibilidade de ser Electra, pensa em aguardar para ouvir um pouco mais e disso se certificar, no que é rechaçado pelo Preceptor, que o lembra do vaticinio de Lóxias - a vitória dependia da libação a Agamenão - e urgia a sua ida ao túmulo. Assim, ainda que quisesse, não poderia poupar a irmã de tomar conhecimento da sua morte.

Electra habita o palácio da familia, carrega o pesado jugo de uma vida em lágrimas, acalenta o desejo de vingança e anseia pelo retorno do irmão. Quando o retirou do palácio e o enviou ao exilio, salvando provavelmente a sua vida, ouviu dele a promessa do retorno, alimento constante da sua alma corroída (p. 31; v. 303ss). Os anos decorridos não amainaram o ódio e o ressentimento dirigidos ao padrasto e à sua mãe. A sensação que temos ao ouvir Electra é que a sua mágoa crescera na mesma medida do seu desamparo. Em idade casadoira não havia quem com isso se importasse, nem com as suas vestes ou com a sua alimentação, ao que ela conclui: "não passo de uma ancila no passo avoengo" (p. 27; wv. 189-190).
Passava a maior parte do tempo reclusa por ordens de Egisto devido à sua insubordinação. Entretanto, aproveitando da sua ausência no palácio, Electra sai e encontra-se com Crisótemis; ambas discutem. Crisótemis, a despeito de sofrer com o assassinato do pai, está resignada e tenta conviver de forma pacifica com a familia; Electra, em contrapartida, não aceita a atitude da irmã e trata-a com aspereza. Crisótemis, ainda assim, se compadece da desdita da irmã e tenta dissuadi-la a mudar de conduta, alertando-a que Egisto trama contra ela: "Escuta o que eu fiquei sabendo: caso não refreies teu pranto, te conduzem aonde não verás raiar o sol" (p. 33; v. 378-381). Electra não teme e mantém a firmeza de antes nos seus propósitos. Crisótemis estava indo fazer libações no túmulo do seu pai por ordens da mãe, após um sonho premonitório, que a deixou perturbada; todavia, Electra convence-a de não fazer nenhum ritual em nome da mãe, mas por elas próprias e pelo retorno de Orestes. Crisótemis acata sem titubeio, solicitando tão somente que o ato permaneça em segredo, temendo os reveses caso descoberto o seu desacato.

Clitemnestra também sai do palácio com um grupo de escravas para libar o túmulo de Agamenão e se encontra com Electra. Clitemnestra aceita que Electra fale, mas o tom do diálogo consentido - é a desmedida. Clitemnestra afirma que o tratamento dado a Electra é justificado devido a sua reação exasperada frente ao assassinato do pai. Para Clitemnestra, o assassinato estava perfeitamente justificado, pois se tratava de reparar a morte da filha, sacrificada pelo marido; ademais, afirma, que "Dike, a justiceira, deu-me o aval, fiz algo em que me secundaras..." (p. 38; v. 528). Electra, por seu turno, justifica o crime paterno e imputa à mãe a intenção única de agradar o amante e com ele permanecer.

Nesse interim, o Preceptor chega ao palácio, noticiando sem rodeios: "Serei sintético: morreu Orestes" (p. 43; v. 673). Podemos imaginar o alcance da dilaceração de Electra neste instante e as angústias que povoaram seus pensamentos: a morte do pai, tramada pela própria mãe, o seu luto solitário, o convivio com o também assassino, e agora padrasto e rei, 
as suas parcas condições materiais, a falta de marido e filhos e, a pior de todas elas, o fim da sua única esperança de mudança - o retorno do irmão. A mãe é completamente imune à dor da filha; pelo contrário, a despeito de qualquer sentimento que possa ter experimentado, o maior deles é, sem dúvida, a ausência do perigo que representava Orestes vivo. Electra, com o "vazio do seu espírito" (p. 48; v. 812) rejeita entrar no palácio e, destituída de alento, num suspiro que imagina derradeiro, avalia: "grata hei de ser, se me vem matar, e, triste, se consentem que eu viva: pesa a vida" (p. 48; vv. 820-822).

Sófocles leva à exaustão como ninguém o páthos ${ }^{4}$ de Electra. Nada mais, nem a sua morte, poderia propiciar o que Electra já não houvesse experimentado. O público, acreditamos, mesmo sabendo que tudo não passava de um plano de Orestes, compadecia-se do fardo suportado pela heroina. À notícia da morte, segue um vivido relato do acidente que vitimara Orestes feito pelo Preceptor. Para Elizabeth Belfiore (1992: 136), "a linguagem tanto quanto os efeitos visuais podem colocar as coisas diante dos olhos". Certamente por isso, a audiência e até nós mesmos, que sabemos que Orestes vive e tudo não passa de um plano, tendemos a acreditar, por uma fração de segundo, na morte de Orestes. Para Aristóteles: "... o Mito deve ser composto de tal maneira que quem ouvir as coisas que vão acontecendo, ainda que nada veja, só pelos sucessos trema e se apiede, como experimentará quem ouça contar a história de Édipo. Querer produzir estas emoções unicamente pelo espetáculo é processo alheio à arte e que mais depende da coregia" (Poét. XIV, 1453b).

Nesse sentido, Sófocles é o que mais explora a carga emocional de Electra, levando ao ápice a função principal da tragédia - a catarse. Não cabe ao poeta outra coisa senão preparar a metábole (mudança), com a cena de reconhecimento.

Crisótemis retorna do túmulo de Agamenão radiante, esperando estender a sua felicidade a

(4) Para Aristóteles, pathós - a catástrofe - "é uma ação perniciosa e dolorosa, como o são as mortes em cena, as dores veementes, os ferimentos e mais casos semelhantes" (Poét. XI 1452b 10).
Electra. O reconhecimento parece estar próximo. Informa à irmã que Orestes está vivo, pois viu "os sinais que eram clarissimos!" (p. 51; vv. 885-886). Sobre a tumba de Agamenão,

Crisótemis encontrou três oferendas: um fio de leite fresco, um círculo floral variegado e um cacho de cabelo recém cortado. O seu raciocinio é lógico, notada a similaridade com os seus cabelos e os de Electra, e afastada a possibilidade de ter sido a mãe a autora das oferendas, ${ }^{5} \mathrm{O}$ cacho só poderia ser de Orestes (p. 51-52; vv. 892-915).

Para Solmsen (1967: 50), "Electra, tendo recentemente ouvido o que ela considera o relato verdadeiro da morte de Orestes, não é capaz de se mexer do seu desespero. Ela se recusa a abrir a sua mente para a nova possibilidade. Excelente psicologia que, tendo perdido a esperança, ela está relutante em aceitar uma nova e agonizante incerteza". O entusiasmo de Crisótemis logo se esvai quando recebe a noticia da morte do irmão. Pergunta quem, então, teria feito as oferendas no túmulo do pai e aceita, sem contestar, a resposta dada por Electra: possivelmente algum simpatizante de Orestes, que lhe tem apreço (p. 53; vv. 932 933). Também é lógico tal raciocinio: Orestes morreu, não é de se estranhar que algum amigo tenha querido prestar tal homenagem ao seu pai e a ele próprio. Não pairando dúvidas sobre a morte de Orestes e o consequente fim das esperanças de sua vingança, Electra recobra as forças, tenta cooptar a irmã para a sua última investida: as duas assassinarem Egisto. Crisótemis

(5) Essa passagem deixa entrever que a herança genética das caracteristicas do cacho de cabelo é materna, uma vez que se cogita a possibilidade de a mãe ser uma das pessoas que poderia ter depositado o cacho de cabelo sobre o túmulo. Em Ésquilo, na cena análoga, Electra afirma que não foi certamente a assassina que depositou ali os cabelos (vv. 185-190). J. Jouanna, em artigo que discute o contexto mítico e cientifico do reconhecimento "pelos pés", utiliza os versos 522 e 523 da Electra de Euripides, nos quais o Velho fala "normalmente, os filhos herdeiros de sangue de um mesmo pai apresentam semelhanças naturais para a maioria das partes do corpo" (Jouanna 1997: 80), para justificar a herança genética paterna, mas silencia em relação às duas passagens, de Ésquilo e de Sófocles, nas quais entrevemos que as caracteristicas são transmitidas pela mãe. 
avalia a impossibilidade da ação para duas mulheres e pede à irmã para desistir, em vão. Electra está decidida: "o que deve ser feito será feito por mim sozinha, do começo ao fim" (p.55; vv. 1019-1020).

É com esta firme disposição que ela se encontra com Orestes, ambos desconhecedores da identidade um do outro. Ele entra em cena com Pilade para cumprir mais uma etapa do plano, levar a urna com as supostas cinzas dele próprio. Segue o diálogo entre ambos:

Orestes: Avisa que homens fócios recémvindos perguntaram aqui fora por Egisto.

Electra: Espero que os rumores que escutamos não sejam confirmados por tua vinda. [...]

Orestes: Portamos nessa urna pequena o que restou de um bravo herói.

$$
\text { (p. 59-60; vv. 1106-1114) }
$$

Electra não titubeia, pede para segurar a urna e aceita a falsa prova como evidência da morte de Orestes. Solmsen avalia a passagem:

[...] no lamento de Electra que segue é mais patético ver como a mesma Electra que no episódio anterior sem hesitação, ou melhor, com algum desprezo repudiou o cacho de cabelos, a genuina evidência de Orestes estar vivo e em Argos, agora, de novo sem a menor hesitação, aceita a urna, a evidência (tecmerion) falsa e enganadora da morte de Orestes, enquanto o próprio Orestes está de pé diante dela (1967: 53).

Não se trata de Electra simplesmente aceitar a urna como a prova da morte do irmão. Faz-se necessário observar o contexto para ver o alcance da capacidade poética e a originalidade de Sófocles. Uma rápida análise psicológica de Electra naquele momento especifico é suficiente para percebermos que não havia outra possibilidade de reação então. Aliada à situação existencial de Electra, devemos levar em conta o fato de ser uma pessoa idosa quem trouxe a notícia, a principio merecedora de crédito, a mando de Fanoteu, tio e inimigo de Estrófio, que com isso agradava a Egisto e certamente desagradava ao próprio Estrófio, além da inexcedivel descrição do acidente feita pelo Preceptor, rica e vasta em pormenores, e, por fim, os próprios restos mortais. Nada mais persuasivo. Como avaliar a situação além do que fez Electra, quando Crisótemis chegou com as provas verdadeiras? Como afirmou Solmsen, em passagem acima, ela já não era capaz de se abrir para novas e agonizantes incertezas. $\mathrm{O}$ ciclo está fechado, tudo se encaixa, não pode pairar dúvidas na cabeça de Electra, mas só uma certeza: Orestes está morto.

Orestes/mensageiro (optamos por esta designação para evidenciar que se tratava de Orestes disfarçado de mensageiro) entrega a urna a Electra, que se dirige a ela como se falasse com o próprio irmão: "Ó recordo, resquicio que ficou da alma do ser que tanto amei! Difere da expectativa de hoje a expectativa de quando te enviei..." (p. 60; vv. 1126-1128). Pensamos que aqui Orestes já está inquieto com a suspeita de que se tratava de Electra, pois no Prólogo, o Preceptor recorda-lhe que "foi nessa casa pluridor que tua irmã Electra me incumbiu de te levar um dia..." (p. 21; vv. 10-14). Se não há certeza da identidade de Electra, pelo menos a angústia da dúvida pairava sobre a cabeça de Orestes. Electra continua dirigindo-se à urna: "Agora, prófugo, extralar, ó mísero, morreste longe da irmã. E eu, com mãos que te idolatram, não lavei teu corpo, não alcei da pira pan-flâmea o fardo (prerrogativa minha!). (p. 61; vv. 1136-1140).

Orestes continua ouvindo e juntando elementos para a conclusão de que estava diante de Electra: "Tua mãe não te amava como eu, não tinhas ama no palácio, só a mim, a quem buscavas, sempre gritando: 'irmã'” (p. 61; vv. 11451148). Acreditamos que esta passagem seja conclusiva para Orestes, as lembranças que tinha de Electra certamente teriam lhe marcado profundamente. Como era ainda menino quando deixou a cidade, ${ }^{6}$ suas recordações

(6) Fitton Brown (1961: 364) acredita que Orestes devia ter entre dez e onze anos, bastante plausivel se tivermos em mente que Agamenão sai de casa e passa dez anos na guerra de Tróia, logo a idade mínima de Orestes seria em torno dos onze anos. 
eram desse curto tempo em que viveu em Argos, mas certamente eram elas que lhe moviam a existência. Ele não pode ter esquecido quem diretamente cuidava dele, a quem ele chamava carinhosamente de "irmã". Ainda nessa fala, Electra acrescenta: "Me enviavas tantas mensagens sigilosas, onde eu lia promessas de vingança em teu retorno" (p. 61; 1154-1156). Orestes ainda teria dúvidas a essa altura? Pensamos que não. Enviara ele mensagens a Crisótemis? A quem ele se refere quando, ao chegar ao palácio, ouve prantos ecoarem do seu interior? Ele pensa que pode ser Electra. Era ela, e não outra, a irmã mais próxima, cúmplice. Se sobraram ainda dúvidas para Orestes estas são dirimidas quando o Coro diz: "Lembra, Electra, você é filha de um pai mortal, e Orestes era mortal. Portanto, não te aflijas em demasia. A morte é uma divida que todos nós devemos pagar" (vv. 1171-1173).?

Orestes não se contém em si de emoção: "Falar o quê? Palauras se embaralham; Percebo que me falha... a lín...gua lân...guida..." (p. 62; vv. 1174-1175). Electra, ainda com a urna em mãos, não está entendendo nada: "tua fala me surpreende. O que te aflige? (p. 62; v. 1176). Orestes lança outra pergunta: "São a mesma pessoa quem vejo e Electra? (p. 62; v. 1177) "Eu sou aquela em condição de espectro" (p. 62; v. 1178), responde Electra. Para Solmsen, a interpretação óbvia de quando Orestes faz a pergunta é de que a fala de Electra tinha aberto os olhos dele quanto à identidade dela, mas ainda encontra dificuldades em aceitar que ela seja realmente Electra:

Ele não pode nessa mulher desgastada pela dor e sofrimento, prematuramente envelhecida e de aparência negligenciada encontrar qualquer coisa como o kleinon eidos [renomada beleza] de sua irmã. Evidentemente ele tinha pensado

(7) Optamos, neste caso, pela transcrição do texto de Richard Jebb (1894), disponivel no Perseus e traduzido por nós, pois enquanto as versões grega e inglesa mencionam o nome de Electra, a tradução portuguesa de Trajano Vieira não o faz e, para a nossa análise nesse momento, este é um dado relevante: "Teu pai era mortal, mortal Orestes também era. Te esqueces? Todos pagam - não te aniquile o pranto! - essa conta" (p. 62; vv. 1171-1173). nela como uma figura radiante, embora em termos gerais ele soubesse da sua infeliz condição, sua imaginação tinha sido incapaz de visualizar nada parecido com a verdade agora diante dele (Solmsen 1967: 54-55).

Dá-se, assim, o término da longa espera de Orestes até o primeiro reconhecimento. $\mathrm{O}$ reconhecimento o surpreendeu e abalou; ele chora, diz que já estava triste só de olhá-la. Certifica-se de estar entre pessoas de confiança, procura saber mais sobre a irmã e o palácio e, finalmente, revela a sua identidade. É a primeira etapa do reconhecimento:

Electra: Então ele está vivo?

Orestes: Se houver alento que me anime a ânima!

Electra: Estou na frente dele?

(p. 64; w. 1220-1222)

Electra não hesitou na aceitação da nova identidade, mas o poeta, ainda assim, lançou mão de um sinal para efetivar a sua comprovação. Orestes acrescenta: "Repara neste anel de nosso pai e diz se estou brincando" (p. 65; vv. 1225 1226). Eis a segunda etapa do reconhecimento.

Sem meandros, assistimos a terceira etapa do reconhecimento: a celebração da identidade revelada e aceitação inconteste. A metabolé é de tamanha envergadura que a alegria extremada quase põe todo plano de Orestes a perder, se não surgisse à porta do palácio o Preceptor, para lembrá-los de que a missão ainda não tinha terminado.

O poeta não explora o sinal - o anel como prova da identidade de Orestes, pois Electra não pede uma prova; ele entra apenas como um reforço. É sintomático, também em Sófocles, a falta de qualquer alusão às oferendas que Crisótemis encontrou sobre o túmulo, sem nem uma menção ao cacho de cabelo. Electra não faz qualquer relação entre o aparecimento de Orestes e o relato da irmã, que passa completamente despercebido na cena de reconhecimento, como um apêndice da peça que não parece fazer parte do seu conjunto. Por que Sófocles teria incluido Crisótemis na peça - só ele o faz - com um papel tão importante e, 
ao mesmo tempo, tão pouco explorado? Seria apenas uma forma de inserir esses sinais assentes no Mito, mas desnecessários para a trama sofocliana? Não pretendemos discutir esta questão. Em Ésquilo, cabe a Electra encontrar as oferendas sobre o túmulo; em Sófocles, a tarefa é de Crisótemis; e, em Eurípides, como veremos, é do Velho.

Solmsen lembra-nos que em Ésquilo e em Eurípides:

O plano e a preparação da vingança se desenvolveram depois do reconhecimento, Electra sendo completamente informada e, em Euripides, ativamente envolvida; nesta peça, Orestes sabe desde o início exatamente como ele procederá. (...) Electra permanece totalmente ignorante do esquema e, após um tempo, quando o plano é colocado em execução, cai ela própria vitima com a decepção. O erro dela é um fator determinante para o desenvolvimento no episódio central (Solmsen 1967: 47).

C Coro não tem um papel tão significativo como vimos em Ésquilo. Em Sófocles, ele é, por vezes, contemporizador: quando Electra lamenta em demasia, ele pede para que ela se contenha, pois não é só ela quem sofre; quando Crisótemis e Electra discutem, ele pede para elas acalmarem os ânimos; e quando Electra fica sabendo da (falsa) morte de Orestes, ele diz que esse é o futuro de todos, por isso não convém o desespero. Isso não significa que ele não compartilhasse da causa de Electra e Orestes: ele se alegra e chora quando do reconhecimento (p. 65; 1230-1231) e, após a morte de Clitemnestra, é ele quem pede para Orestes e Electra terem cuidado, pois Egisto já estava chegando e poderia perceber o que estava acontecendo (p. 73; v. 1429).

\subsection{Em Eurípides}

Na Electra de Euripides, peça possivelmente representada em 415 a.C., o prólogo inicia-se com o monólogo de um camponês micênio e pobre, a quem Egisto deu Electra em casamen- to, temendo que ela contraísse matrimônio com um nobre, de onde poderia surgir um herdeiro de Agamenão, igualmente nobre, que o vingasse. Ele nos dá conta de que Egisto pensava em eliminar Electra, mas Clitemnestra não permitia (p. 82; vv. 25-28); certamente acreditava que fosse suficiente afastá-la do palácio com o desalinhado matrimônio. Quanto a Orestes, o padrasto também almejava eliminá-lo. Os filhos de Agamenão, únicos herdeiros, representavam uma séria ameaça ao poder de Egisto. O camponês é generoso com Electra, mantendo-a virgem, e embora ela sofra com a união indigna à sua linhagem, é agradável para com o marido e tenta retribuir: És como um deus de quem eu fosse amiga, avesso a perversões em minha agrura. Alegre a moira de quem ache um médico que o cure da moléstia: assim te vejo!... (p. 83; vv. 67-70).

Electra e o camponês saem de cena e entram Pilade e Orestes, que regressaram à Argos em segredo, como o fizeram também em Ésquilo e Sófocles, guiados pelo oráculo de Apolo, com o objetivo de vingar os assassinos de Agamenão. Orestes diz que na noite anterior visitou o túmulo paterno e fez oferendas: "depus cabelos de angústia, espargi no altar o sangue da ovelha que imolei" (p. 84; vv. 90-92).

Orestes sabe que Electra é recém-casada, morando longe do palácio, e quer se associar a ela no plano de vingança: "Quem lavra a terra logo vem aqui ou uma ancila a quem perguntaremos se minha irmã habita perto" (p. 82; vv. 104-106). Logo avista alguém e imagina ser uma escrava, não tarda para, em suas primeiras palavras, reconhecer naquela "escrava” a irmã: Oh! Dor! Oh! Dor! Agamêmnon, o hegêmone, gerou-me e Clitemnestra, tindarida estígia. Nos oráculos da pólis chamam-me Electra, circunspecta (p.85; vv. 114-119).

Mesmo supondo que Electra vivesse em condições dificeis, não poderia pensar que a moça transportando água de um riacho, com o cabelo raspado, de penteado rústico e túnica tosca (p. 87; vv. 175-185), pudesse ser a sua irmã. Antes que ele pudesse esboçar qualquer reação, aproximou-se de Electra um grupo de mulheres, o coro, composto por moças da Argólida, para convidarem-na a um festejo da comunidade rural; ela, de pronto, recusou. 
Orestes e Pilade aproximam-se. Electra, amedrontada, sem saber de quem se tratava, pede ao Coro para seguir e avisa que vai entrar em casa. Não dá tempo, e Orestes as aborda. No monólogo anterior, Electra não deixou qualquer dúvida quanto a sua lealdade a Orestes. Ela expôs não só seu sofrimento, mas o desejo pelo retorno do irmão; todavia segue um duro teste, e o reconhecimento é retardado ao máximo. Várias oportunidades são perdidas, como quando Orestes a vê acuada, sem saber de quem se tratava. Quando ele diz: "Posso tocar em ti mais do que em outro" (p. 88; v. 224), poderia ter revelado sua identidade nesse instante, mas nos deixa em suspense. Electra interroga-o: "por que empunhavas, sorrateiro, a espada?" (p. 88; v. 225). Ouvimos então uma resposta e imaginamos que dai sairá a revelação da identidade: "escuta-me e nos poupa de tolices" (p. 88; v. 226). Orestes principia um relato enganoso, passando-se por um mensageiro que veio trazer noticias de Orestes. Informa-a que ele está vivo. Se em Euripides Electra tem a vantagem de saber rapidamente que o irmão está vivo, tem a desvantagem de ter o reconhecimento postergado por longo tempo. Em Sófocles, Orestes tem desde o início vontade de saber sobre a irmã e quando ouve prantos ecoarem do interior do palácio, rapidamente imagina que pode ser Electra, mas é obrigado a ir ao túmulo, libar ao pai, condição indispensável para prosperar no seu intento. Ao retornar, não resiste ao se deparar com a irmã e logo revela a sua identidade. Não a ter poupado do relato da sua morte deveu-se à impossibilidade de fazê-lo.

Segue o diálogo entre o mensageiro/ Orestes e Electra. Ela deixa claro o amor inabalável que nutre pelo pai e pelo irmão: "Meu pai e meu irmão são minha vida" (p. 89; v. 243). Ele responde: "Orestes compartilha o sentimento" (p. 89; v. 244). Pensamos no espectador frente às oportunidades perdidas; certamente esse foi um momento em que aquele que assistia à peça quase completava a fala de Orestes. Mas o mensageiro/Orestes passa a inquiri-la sobre a sua vida. Electra mostra a casa, fala sobre o marido, contrariada pelas núpcias hórridas (p. 89; v. 247). O
mensageiro/Orestes quer ter a certeza de que se encontra entre pessoas amigas: "podemos confiar em quem nos ouve?" (p. 91; v. 272), o que lhe é assegurado por Electra: "Nada dirão do que entre nós for dito" (p. 91; v. 273). O diálogo prossegue. O mensageiro/Orestes ouve de Electra que se Orestes regressasse se aliaria a ele para eliminar os assassinos do pai com o mesmo instrumento com que ele foi morto. A resposta para tantas oportunidades perdidas é oferecida por Solmsen: "não Orestes, mas Euripides deseja manter-se na prossecução do jogo tão cheio de surpresas e frustrações" (1967: 41). Para Adriane da Silva Duarte "toda a passagem evidencia o quanto Euripides discute e problematiza o processo de reconhecimento" (2005: 162).

Electra não é capaz de reconhecer o irmão, e isto está bem claro na conversa mantida entre eles; foram separados quando ele era ainda criança. Orestes sabe que só há uma pessoa capaz de reconhecê-lo, o velho que o salvou do palácio e o levou ao exilio (p.92-93; vv. 285 287). A esta altura, o público, ou pelo menos parte dele, já devia esperar que Orestes não se revelasse espontaneamente, mas fosse reconhecido por esse homem. Para Solmsen (1967: 44), Euripides revela grande engenho e desenvoltura, criando repetidamente condições propicias para o reconhecimento e quando ele atinge o ponto crucial deixa nossa expectativa frustrada.

O camponês retorna ao lar e, passado o susto por ver Electra conversando com homens estranhos, toma conhecimento de que se tratava de amigos de Orestes; logo passa a tratálos dentro do contexto tão caro aos gregos - a hospitalidade. Os parcos recursos não são impedimento para o camponês e Electra dispensarem aos hóspedes o mais caro tratamento. Electra pede ao marido para ir à casa do velho amigo da familia, que salvou Orestes da morte, para ele vir saber das novas e trazer provisões para os hóspedes.

O Velho chega ao casebre de Electra cansado e bastante emocionado; chora, pois se desviou do caminho para visitar o túmulo de Agamenão e fazer-lhe oferendas. Ao chegar lá, deparou-se com uma ovelha recém-imolada sobre o altar e um cacho de cabelos loiros recém cortados (p. 99; vv. 509-515). Electra sai 
à porta para recebê-lo. O Velho informa a Electra o que acabou de ver e levanta a suspeita: "será que Orestes não chegou calado e, no ato inaugural, rendeu as loas ao pai? Compara a cor desta melena com a do teu cabelo, pois herdeiros de sangue de um só pai soem possuir idênticos aspectos corporais" (p. 100; wv. 517-522). Electra descarta, uma a uma, tais possibilidades: 1) um nobre como Orestes não retornaria às escondidas; 2) os cabelos de um jovem são naturalmente diferentes dos cabelos de uma moça, que tem mais cuidados; 3) o tom idêntico da mecha dos cabelos não é exclusividade de parentes. Mas o Velho, convicto do que estava dizendo, insiste: "pisa nos rastros dos calçados dele e observa se as pegadas são simétricas" (p. 100; vv. 532-533). Continua Electra: "E como o pé se imprime no terreno pedregulhoso? Se deixasse marcas, isso não queria dizer que irmãos têm pés iguais, pois homens calçam mais" (p. 100; vv. 534-537). ${ }^{8}$ Resoluto, conjectura o Velho: "Não há - se teu irmão voltasse - alguma roupa que lhe teceste, quando foi embora, e que ao rever, dirias: é dele?" (p. 100; vv. 538-540). Electra não vê qualquer sentido na fala do Velho, acha que ele está fora do juizo: "Ignoras minha idade quando Orestes partiu? Mesmo se eu the tecera roupas, como haveria de o então menino usálas hoje, se não crescessem com seu corpo?" (p. 100; v. 541-544).

Concordamos com os comentadores modernos (Brandão 2001: 115-129; Joanna 1997: 69-85; Mezzadri 1997: 89-105; Oliveira 2006: 133-143) quando afirmam que Euripides está fazendo alusão às Coéforas. ${ }^{9}$ Natural, pois ao que tudo indica a obra de Ésquilo havia se tornado um clássico na época de Eurípides e

(8) Para Pietro Pucci, tanto em Ésquilo quanto em Euripides o desenrolar da cena está baseado na crença. "Em Ésquilo, a aceitação da evidência decorre do fato religioso de que somente Orestes poderia fazer a oferenda [do cacho de cabelo]; em Eurípides, a rejeição à evidência depende da crença de Electra na nobreza do irmão" [um nobre não retornaria às escondidas] (1967: 369).

(9) Para Gilberte Ronnet, não aparece em qualquer texto que faça referência às Coéforas na Antiguidade a interpretação de que Euripides estivesse fazendo uma critica a Ésquilo: "não se encontra ai [na Antiguidade] qualquer alusão nem em Aristófanes, que teria material para alimentar a disputa dos dois antagonistas em As povoava o imaginário do espectador. Ela foi, das três peças trabalhadas, a única mencionada por Aristóteles, conforme citação anterior (Poét. XVI, 1455a 5). Aristófanes faz referência ao raciocinio lógico de Electra na parábase de As Nuvens, entre os versos 518 e 562, e a encontramos retratada em vários vasos cerâmicos, como é o caso de pelo menos cinco, de um pintor do século IV a. C., conhecido como o Pintor das Coéforas, justamente por ter cinco dos cinqüenta e cinco vasos que lhes são atribuídos com cenas das Coéforas; entre elas a do encontro de Orestes e Electra no túmulo paterno (Dias 2009: 14).

Refutando todas as evidências, Electra é conclusiva: "... Foi algum forasteiro quem depôs os cachos, ou algum espião de Orestes" (p.100; vv. 545-546). Toda questão aparentemente está superada, mas é sintomático que o Velho diga: "Cadê os hóspedes, que eu lhes indago sobre seu mano, olhando-os bem no rosto" (p.101; vv. 547548). O poeta quer chamar a atenção do espectador para a cena de reconhecimento, o velho fitará o rosto dos mensageiros. Mais do que a audição do relato dos mensageiros, é o ver que é ressaltado. Não por outro motivo, o Velho, assim que vê Orestes, encara-o avidamente. Nós que estamos lendo a peça, e não na sua audiência, conseguimos imaginar o rosto do velho completamente transmudado pela descoberta (talvez a sua audiência nem percebesse esse detalhe; poderia estar o ator usando máscara).$^{10}$ É o Velho quem reconhece Orestes, como era de se esperar, e revela a sua identidade à Electra: "Invoca os deuses já, querida Electra! [...] Pelo tesouro que te oferta um deus. [...] Repara

Rãs, nem em Aristóteles, que aprova a cena de Ésquilo sem parecer saber que ela jamais foi contestada. De fato, ninguém revela esta pretendida paródia, tanto que se admira Euripides, isto é, até o século XIX, e sua denúncia parece ser o fato de Schlegel, cuja aversão por Euripides apenas cede a seu desprezo por Racine: Euripides encarna, aos seus olhos, a decadência da tragédia" (Ronnet 1975: 64).

(10) Essa questão de máscaras, coturnos e artifícios utilizados pelos atores é ventilada na análise da Electra de Ésquilo por Fitton-Brown (1961: 366), mas não pretendemos avançar neste ponto. 
nele: tem o que mais queres" (pp. 101-102; wv. 563 567). Electra pensa que o velho está fora de si e não sabe o que diz: "Teu ânimo esmorece há muito tempo" (p.102; v. 568); mas insiste o homem: "Como esmorece, se quem vejo é Orestes?" (p. 102; v. 569). A descrente e sarcástica Electra continua: "Não faz sentido a tua fala esdrúxula" (p. 102; v. 570). Para Electra, a fala do Velho continuaria um disparate, não obstante a segurança daquelas palavras: "Vês Orestes, o filho de Agamêmnon!" (p. 102; v. 571). Electra, fria, impassivel, querendo pôr fim ao que imaginava fruto da senilidade do Velho, pede provas: "Há traço nele com que me convenças?" (p. 102; v. 572). O velho, muito confiante, lembra a Electra de um acidente que Orestes sofreu ao brincar com ela, e da conseqüente cicatriz no seu supercilio (p. 102; vv. 573-574): é a segunda etapa do reconhecimento.

Para Pietro Pucci, Eurípides está lidando com um tema que é mais caro a ele do que a Ésquilo e seu tempo - a relação entre evidência e verdade. "O raciocínio sólido de Electra está errado. Ela está certa por algum padrão de análise racional da evidência, e já está errada. Euripides aqui repete seu tema familiar da impotência da razão humana" (1967: 369). Para Gilberte Ronnet, não se trata de Eurípides estar esboçando o seu pensamento, tecendo criticas à trama de Ésquilo, mas traçando o perfil de Electra. "O fato é que as palavras dele [Euripides] reproduzem uma cena célebre e admirada, dando-lhe autoridade, e contribui para caracterizar a heroina em sua arrogante falta de entendimento e sublinhar a sua cegueira. [...] Esta cena é importante para caracterizar Electra, que ai perde mais um pouco da simpatia que lhe valia seus males" (1975: 70). O autor acrescenta que os indícios encontrados pelo Velho e toda a questão levantada são fundamentais para que ele examine com interesse e indiscrição o estrangeiro, descobrindo a cicatriz que lhe fará reconhecer Orestes; por isso, se as sugestões do Velho fossem descabidas, a reação de Electra seria justificada. Mas são precisamente as referências a Ésquilo que são úteis (Ronnet 1975: 67-69). Como frisa Adriane da Silva Duarte (2005: 163), é a cicatriz que convence Electra, mas isso não prova que as conclusões do velho estavam erradas; assim, o raciocinio da Electra de Ésquilo foi confirmado. Os "acréscimos esquilianos", as pegadas e as vestes, só podem ser entendidos como uma forma de o poeta equiparar a sua peça à clássica Electra e atender aos convencionalismos das cenas de reconhecimento, ${ }^{11}$ o que notamos também em Sófocles, mencionado anteriormente, quando inclui a visita de Crisótemis ao túmulo e depois não explora seus resultados. Concordamos com a autora supramencionada e tomamos de empréstimo a citação de Goldhill em seu texto:

"A intertextualidade com Ésquilo, a transposição dos sinais de reconhecimento da Orestia para uma narrativa diferente, não somente enfatiza o vínculo genético que a peça de Euripides mantém com a tradição teatral [...], mas também evidencia o convencionalismo dos mecanismos de reconhecimento"

(Goldhill 1992, apud Duarte 2005: 163).

Diante das evidências, Orestes, que tinha se mantido calado, já não poderia, se quisesse, desmentir. Diferentemente das peças anteriores, ele não teve qualquer controle sobre o reconhecimento. Dá-se assim a terceira etapa do reconhecimento: o festejo de todos os presentes.

Em seguida, os esforços são direcionados para a preparação dos planos para o assassinato de Egisto e Clitemnestra. Bem ao gosto de Euripides, de inserir em suas peças personagens de camadas sociais baixas, o Velho é um personagem chave no planejamento da trama. Diga-se de passagem, como nos chama a atenção Gilberte Ronnet, o papel do velho é significativo em toda peça: 1 ) ele salva Orestes criança e manda-o para o exílio; 2) ele reconhece Orestes; e 3) ele traça o plano do assassinato de Egisto (1975: 69).

Em Ésquilo, o reconhecimento é central para o desenrolar da trama, por isso tão rápido

(11) Para Pietro Pucci, o significado da função artística da convenção da cena de reconhecimento é mais importante do que a sua plausibilidade (1967: 365). 
no primeiro episódio. Electra é fundamental para traçar o plano de assassinato com Orestes, em seguida ela retorna ao palácio, fingindo que nada aconteceu, e desaparece da peça para não mais retornar; tudo o mais é feito por Orestes. Para E. Belfiore (1992: 158), "o reconhecimento se dá junto com a peripécia, marcando o começo da mudança da má para a boa fortuna”. Esta afirmação pode ser estendida às duas outras peças. Em Sófocles, todo o plano está pronto quando Orestes chega a Argos, e Electra está de fora dele. Seu papel resume-se a vigiar a porta do palácio enquanto Orestes, no seu interior, comete o matricídio. Além disso, quando a mãe é golpeada por Orestes, Electra solicita ao irmão que desfira um segundo golpe, e é atendida (p. 73; w. 1415-1417). Em Euripides, Electra é fundamental para a trama e a consecução do assassinato, participando direta e ativamente do matricidio, instando o irmão a não se apiedar da mãe quando ele titubeia, ${ }^{12}$ papel que cabe a Pilade na peça de Sófocles, sua única fala nas três tragédias.

\section{Um exercício de pensar o espaço nas cenas de reconhecimento}

Coloquemos de antemão uma questão sobre o espaço: Argos ou Micenas? A literatura antiga parece não apresentar um consenso sobre a utilização desses termos. A despeito de não pretendermos nos debruçar sobre este tema, vejamos, sinteticamente, como Irene Chalkia trata a questão para os casos de Homero, Ésquilo, Sófocles e Euripides:

[...] parece que na Ilíada, Argos e Micenas são duas cidades diferentes e bem distintas. Mais precisamente se se leva em conta termos de qualificação que acompanham o topônimo Argos na Ilíada. Percebe-se que Argos não designa

(12) Para Gilberte Ronnet, Orestes se mostra contrário ao que deveria ser: enquanto herdeiro do rei de Argos, ele é pusilânime, indeciso e se deixa levar ora pelo Velho ora pela irmã; a virilidade não é uma característica sua, mas de Electra (1975: 69). uma cidade, mas uma região, a Argólida [...]; parece, ao contrário, que Micenas só pode ser identificada com a própria cidade [...]. Em Ésquilo, constata-se a total ausência dos termos Micenas e micênios, o que é bastante surpreendente se pensarmos que a Oresteia se desenrola quase inteiramente diante do palácio de Agamenão [...]. Ésquilo utiliza exclusivamente os termos Argos e argivos, como se pode ver na Oresteia, n'As Suplicantes, em Os Sete contra Tebas e em Prometeu. Contrariamente a essa surpreendente ausência do termo Micenas ou micênios em Ésquilo, podese encontrar em Sófocles cinco ocorrências onde esses termos aparecem ao lado de Argos e argivos, quatro delas em Electra [...]. Como em Homero [em Sófocles] constata-se que Argos é empregado no mesmo contexto que Micenas, na mesma passagem (o prólogo) e pelas mesmas pessoas para designar tanto a região da Argólida quanto a cidade de Argos. Na Electra [de Euripides], as referências a Argos (em número de dez) se ligam ao território, ao pais ou à cidade de Argos, tanto quanto ao lugar onde se encontram o palácio dos Atridas e para onde o retorno de Orestes é projetado. Poder-se-ia dizer que Argos designa ao longo da peça a um só tempo um espaço evocado e um espaço representado, já que se fala tanto em Argólida (espaço representado) quanto da cidade de Argos (espaço evocado) (Chalkia 1986: 151-152 e 175).

\subsection{Em Ésquilo}

N'As Coéforas pretendemos refletir sobre dois aspectos mais de perto: 1) a ligação da cena de reconhecimento, ocorrido no espaço tumular, e a correlação com o culto ao herói; e 2) a mudança operada, em Atenas e também no Egeu, nos hábitos de enterramentos, permitindo ou restringindo a monumentalização, e a possivel relação com o fato de Ésquilo ter supervalorizado o túmulo na representação da peça.

Transcorridos os anos, Orestes volta à 
Pátria e, ao fazê-lo, é ao túmulo ${ }^{13}$ do pai que primeiramente se dirige, encontrando e reconhecendo ai a sua irmã, Electra, onde conjuntamente arquitetam o plano de assassinato.

Grande parte da peça transcorre no túmulo: até o verso 651, o que significa todo o primeiro episódio. Em seguida, abrindo o segundo episódio, Orestes já está à porta do palácio, onde se passa por estrangeiro e dá a notícia a Clitemnestra da morte de Orestes. Esta manda a ama avisar a Egisto. Nesse interim, a ama encontra-se com o Coro, que havia permanecido no túmulo (vv. 720-838). Ou seja, dos menos de 1100 versos da tragédia cerca de 770 são encenados ao lado do túmulo.

A prece de Orestes ao pai começa logo nos primeiros versos: "Do alto deste túmulo a ti dirijo o meu apelo, pai! Atende! Escuta!... (vv. 4-5). Electra chega com o Coro para as libações ao pai e compartilha com o Coro o mesmo sentimento de respeito ao túmulo:

Corifeu: É venerando o túmulo de teu pai como um altar que te vou dizer, visto que mo ordenas, o que tenho no coração.

Electra: Fala, animado como estás por esse sentimento de respeito que testemunhaste pelo túmulo de meu pai.

O túmulo revela-se como espaço que se abre e nutre de esperanças os irmãos, participes do mesmo vazio que a ausência paterna causara e, munidos de um só ideal, a eliminação dos assassinos do pai, ainda que um deles fosse a própria mãe. Electra evoca o pai: "Escuta também, pai, a minha dor insaciável de gemidos. Dos teus dois filhos o trenó ergue-se, soluçante, sobre o teu túmulo, é um túmulo que nos acolhe, suplicantes e exilados" (vv. 330-336).

(13) David Wiles (1988: 82-85) discute quais os elementos utilizados no cenário da peça: um túmulo, um altar, ou antes, os dois. Para ele, havia somente um altar no centro da orquestra para a representação de toda a trilogia de Ésquilo. Nossa discussão não passa, a principio, pelos artifícios que a coregia lançou mão para representar o que o poeta menciona no texto, mas pelos elementos evocados pelo poeta, o túmulo e o altar, dentre outros.
Para Susan Alcock (1991: 447), o "túmulo dos ancestrais torna-se um lugar de poder e conforto para uma comunidade, sobretudo nos periodos de conflitos sociais e mudanças". A autora acentua que a maior incidência de culto ao túmulo ancestral ocorre reiteradas vezes em periodos de transição e stress para a pólis. É exatamente um desses momentos de tensão que podemos perceber em Ésquilo. Orestes, filho do rei assassinado, é afastado da sua cidade ainda menino, mas regressa, agora um homem, um vingador. Alia-se à fiel irmã e a um pequeno séquito para recobrar o trono paterno, usurpado pelos assassinos do seu pai, e assumir o lugar de chefe supremo da cidade, pois não suportava a idéia de que "cidadãos de alma nobre, os mais ilustres mortais, os destruidores de Tróia, estejam assim submetidos a duas mulheres; porque o coração dele [Egisto] é de mulher" (vv. 300-305). A memória de Agamenão deveria ser preservada no espaço da cidade. Sabemos que não é este o desdobramento da tragédia, mas podemos supor que fosse o desejo de Orestes.

O túmulo paterno, assim, é mais que um local de adoração; é, em si, a personificação da entidade benfazeja e redentora. Observemos essas duas passagens:

Electra: Também eu, uma vez na posse da minha herança, sairei da casa paterna para te oferecer libações no dia das minhas núpcias e o teu túmulo será o primeiro objeto da minha veneração.

(vv. 485-490)

Corifeu: [...] Ó solo venerável, ó venerável construção tumular, que cobres o corpo de um rei, comandante da frota, escuta-nos, vem em nosso auxílio.

(vv. 720-725)

O túmulo recebe de Electra a promessa de ser não um objeto de adoração, mas o primeiro, colocado acima de qualquer outra possibilidade, talvez até das divindades. Para o Corifeu, por seu turno, não só o túmulo, mas também o solo que o abriga é venerável.

Maria Beatriz Borba Florenzano, ao indagar qual a crença dos gregos a respeito do lugar para onde iria o espírito depois da morte, 
se permaneceria junto ao corpo, no túmulo, ou se iria para o Hades, afirma que "nos lécitos de fundo branco, as duas possibilidades são visiveis: de um lado cultua-se o túmulo, a estela, como se fosse o próprio morto, e de outro representa-se a viagem que realiza o morto para o mundo do Além" (Florenzano 1996: 83).

Nesse sentido, é possivel pensarmos que tamanha ênfase e profunda emoção dos personagens se devessem ao fato de acreditarem que ali residia o espírito de Agamenão, aliada à crença de que era possivel ao morto interferir de alguma maneira sobre o destino dos vivos. Orestes clama fervorosamente: "É a ti que invoco: vem, pai, em socorro dos que te amam" (v. 456). ${ }^{14}$

A despeito de não ter sido aquele túmulo nem aquele tipo de morte que os filhos esperavam para o herói de Tróia e pai querido, à tumba se dirigem com devoção máxima e absolutamente sincera:

Orestes: Não teres sucumbido, pai, junto às muralhas de Tróia, trespassado pela lança de qualquer guerreiro lício! Deixando na tua casa um nome glorioso e legando aos teus filhos uma vida, que, à tua passagem, neles fizesse concentrar os olhares de todos, tu terias, além-mar, um excelso túmulo de terra, que tornaria a tua morte mais suportável aos teus. $[. .$.

Electra: Ah! Que em vez de teres tombado, pai, junto às muralhas de Tróia, entre os outros guerreiros vencidos pela lança, e de teres sido sepultado nas margens do Escamandro, tivessem sido os teus matadores a sucumbir assim! Poderíamos receber aqui a notícia de sua morte lá longe, sem experimentarmos todas estas angústias.

(vv. 344-355)

O desejo de Orestes e de Electra era o de qualquer outro grego presente no teatro no dia da representação da peça, traduzido no ideal do que Jean-Pierre Vernant (2002)

(14) Irad Malkin afirma que os libios costumavam consultar as tumbas ancestrais sobre sonhos oraculares (1987: 6). chamou de a "bela-morte". É a este ideal grego que Orestes e Electra se reportam. Ninguém merecia mais do que aquele que de Zeus recebera o cetro, como já dissemos, cair nas primeiras fileiras, guerreando bravamente pela Pátria: eis a exposição da sua thimé. ${ }^{15}$ Tombado pela mão do inimigo de forma corajosa, no campo de batalha, Agamenão teria recebido as honrarias concedidas pela cidade e as benesses seriam estendidas à família. A memória do herói seria resgatada nas orações fúnebres, nos monumentos aos mortos na guerra e ecoaria na voz do aedo, repetindo a cômputa das suas façanhas aos compatriotas, que se comprazeriam em acariciar os ouvidos, tendo-o como modelo. Podemos ver na llíada os rituais dos heróis tombados na guerra e a importância que lhes era dada; não é por acaso que o último verso dessa epopeia aluda ao rito prestado ao valente guerreiro troiano: "E assim foi o funeral de Heitor, domador de cavalos" (XXIV, 804). A glória imorredoura é traduzida mais tarde no culto ao herói. Mas de tudo isso Agamenão é alijado, pois não há mérito, e sim demeritus, em morrer pelas mãos daqueles que deveriam amá-lo e protegê-lo.

O culto ao túmulo originou-se possivelmente na Idade do Bronze, intensificando-se no início da Idade do Ferro (Antonaccio 1999: 115). Nas escavações em túmulos foram encontradas cerâmicas, placas votivas, taças, vasilhas, ânforas, dentre outros objetos, e evidências de sacrifícios, como cinzas ou ossos de animais (boi, vaca, cavalo, porco, tartaruga, ave), além de um santuário ou um altar nas vizinhanças do túmulo (Alcock 1991: 449).

Segundo Carla Antonaccio, o culto ao herói é arqueologicamente verificável somente do VIII para o século VII a.C., e o primeiro seguramente identificado é o de Helena e Menelau. Acrescenta a autora, o culto ao túmulo não cessou quando o culto ao herói se

(15) "O valor proeminente de um individuo, ou seja, ao mesmo tempo, sua hierarquia, os privilégios e as honras que tem direito de exigir e sua excelência pessoal, o conjunto das qualidades e dos méritos que demonstram que ele faz parte de uma elite, de um pequeno grupo dos áristoi, dos melhores" (Vernant 2002: 407). 
intensificou, e persistiram ao lado um do outro, conforme registros em algumas regiões, até o periodo helenístico (1999: 115).

$\mathrm{O}$ culto ao herói foi frequentemente retomado pelos gregos. $\mathrm{O}$ fundador de uma colônia - oikista - ao morrer recebia o culto ao herói. Nos periodos helenístico e romano, as familias da elite cooptaram túmulos e rituais para o seu próprio uso, proclamando-os monumentos de antepassados; tratava-se de uma estratégia para anunciar e legitimar uma nova autoridade dentro da comunidade (Alcock 1991: 458). A elite traçava a sua árvore genealógica identificando-se como descendentes dos heróis mitológicos. Não é nosso intuito tratar desse aspecto neste momento, mas apenas salientar a força que representava para o grego o culto ao herói.

Nesse sentido, o século VIII a.C. marca, não sem divergência entre os estudiosos, a alavancada inicial de várias pólis rumo à constituição de colônias. Antonaccio (1999: 110) lembra a passagem da Odisseia (VI, 7-11), na qual o poeta narra a fundação de Esquéria por Nausitoo e as suas realizações; menciona Plutarco e Tucidides, informando sobre a fundação de colônias, o status de herói e o culto que o oikista recebia depois da morte. Segundo Jean-Pierre Vernant, no século VIII a.C., aliado ao desenvolvimento das cidades, surge o costume do reaproveitamento das construções micênicas, funerárias em sua maioria. Elas são reformadas e tornam-se locais de culto:

O culto dos heróis tem um valor ao mesmo tempo cívico e territorial; está associado a um local preciso, um túmulo com a presença subterrânea do defunto, cujos restos foram às vezes buscados em regiões distantes para serem conduzidos ao seu lugar. Túmulos e cultos heróicos, através do prestígio do personagem homenageado, exercem para uma comunidade o papel de símbolo glorioso e de talismã (Vernant 2006: 44) .

Não é de se estranhar que Ésquilo tenha querido homenagear Agamenão com o culto ao herói, pois o seu irmão, Menelau, era celebrado pelos Lacônios com um dos cultos mais antigos e monumentalizados, segundo Antonaccio (1999: 117). ${ }^{16}$ Menelau representava os tempos gloriosos dos vencedores da guerra de Tróia - o passado épico - e também um passado prédórico, a ligação necessária, para a nova cidade, entre o passado triunfante e o presente ao qual almeja se assemelhar.

O túmulo está ligado à ancestralidade, ao culto ao herói, a valores mais arcaicos cultuados por Ésquilo, diferentes de Sófocles e Euripides. As suas produções distam cerca de quarenta anos, portanto um contexto social, politico e cultural diferentes. Para Ésquilo, Electra e Orestes representam a tradição e o oîkos paterno, rompidos com o assassinato e só possiveis de serem restabelecidos com a justiça, proporcionada apenas pela eliminação dos homicidas.

Outro aspecto sobre o qual pretendemos refletir diz respeito à monumentalização dos túmulos. Sabemos que, entre os gregos, era inaceitável permanecer insepulto após a morte. O exemplo clássico é o desespero de Antigona e a sua coragem desmesurada, que a leva às últimas consequências, no afã de enterrar o seu irmão, ordenado pelo rei Creonte a permanecer sem sepultura. Situações de exceção, é claro, existiram, como os periodos de peste extremada e guerra, em que muitas pessoas, por forças maiores, já não observavam os costumes e enterravam os seus mortos como podiam, inclusive aproveitando-se de piras alheias para lançarem os corpos indiscriminadamente, como nos relata Tucidides (História da Guerra do Peloponeso II, 52). Afora isso, mesmo aqueles que morressem longe de casa deveriam ter um túmulo simbólico e os indispensáveis rituais. Para Maria Beatriz Florenzano, "os documentos atestam também que a execução dos rituais funerários consistia em um momento privilegiado no qual uma família, ou um grupo social, podia exibir suas glórias, sua riqueza, sua

(16) Para Antonaccio, "o culto ao herói é arqueologicamente verificável para os séculos VIII e VII a.C., e o primeiro seguramente identificado é o culto a Helena e Menelau" (1999: 115). 
importância na comunidade. Entre os gregos isso se traduziu em uma tendência à sofisticação e à monumentalização das sepulturas" (1996: 66).

A monumentalização das sepulturas é um fenômeno observado até o século VI a.C. Segundo o arqueólogo I. Morris, em torno de 500 a.C. declina a ostentação dos túmulos por toda parte, devido a restrições legais quanto à suntuosidade das sepulturas, e a partir de 425 a.C. ocorre uma acentuação generalizada de exposição de riquezas nos túmulos, fenômeno genuinamente pan-helênico (Morris 1992: 2).

Paula Falcão Argolo (2001), em seu estudo sobre os Ritos Funerários e Leis Suntuárias da Pólis, analisa alguns documentos referente a essas leis: 1) o livro dois das Leis (De Legibus), de Cícero; 2) Vida de Sólon, de Plutarco; e 3 ) o discurso Contra Macartatus, de Pseudo-Demóstenes. Plutarco e Pseudo-Demóstenes fazem referências à mesma lei, portanto relativa ao período em que Sólon exerceu o arcontado em Atenas (592 591 a.C., possivelmente). Nessas leis são estabelecidas restrições relacionadas às lamentações ao morto, aos prantos exagerados, à indumentária feminina e à quantidade de comida e bebida levada no cortejo fúnebre, bem como aos sacrifícios de animais na tumba (Argolo 2001: 3). Essa documentação nada menciona sobre a ostentação na construção do túmulo; portanto, não serve ao nosso propósito, neste momento, mas nos faz pensar que esse já era um assunto em pauta naquele período. O De Legibus, de Cícero, pelo contrário, a despeito das poucas informações, da datação incerta a que Cícero se refere (possivelmente o periodo de 510-480) e da distância temporal entre o autor e o evento tratado, é bastante esclarecedor para o nosso propósito - examinar as restrições legais à construção tumular. Passemos em revista o trecho 26.64-65, conforme transcrição da autora acima mencionada:

Algum tempo depois [das leis de Sólon], devido ao enorme tamanho das tumbas que agora vemos no Cerâmico, ficou determinado por lei que ninguém deveria construir uma sepultura que exigisse mais trabalho do que aquele que dez homens pudessem completar em três dias. Também não eram permitidos adornar a tumba com opus tectorium [conforme nota da autora, placas votivas de terracota que cobriam a tumba] nem erigir pilares sobre elas. Discursos que louvassem o morto também foram proibidos, exceto nos funerais públicos, onde atuavam oradores oficialmente apontados para este propósito. Foi proibida, ainda, a aglomeração de um grande número de homens e mulheres, com o intuito de limitar o pranto presente nas lamentações (Cícero, De Legibus 26.64-65; apud Argolo 2001: 6).

Cícero nos fala sobre as grandes construções tumulares encontradas ainda em seu tempo, e como depois de Sólon elas foram proibidas legalmente, restringidas a um número especifico de dias para ficarem prontas e a um número máximo de trabalhadores que poderiam ser utilizados, o que limitaria a sua monumentalização, sobretudo a proibição de pilares e mesmo placas votivas. Se essa lei ainda estava em vigor no periodo em que Ésquilo apresentou a sua peça Coéforas, 458 a.C., e acrescentarmos os relatos arqueológicos de Ian Morris (1992), teremos argumentos suficientes para deduzir que Ésquilo ambientou grande parte de sua peça no túmulo - com momentos-chaves da trama, como o encontro e o reconhecimento entre Orestes e Electra, e o planejamento da vingança - para chamar a atenção da sua audiência para aquelas restrições. $\mathrm{O}$ túmulo poderia, possivelmente, ser um quadro de referências entre autor e espectador, se levarmos em conta a interdição a construções tumulares suntuosas impostas à cidade, sobretudo se nos atentarmos para o fato de que nem toda comunidade comungava dessas restrições. Há registros arqueológicos que atestam a existência de familias que por três gerações insistentemente ignoraram as restrições de ostentação (Argolo 2001: 4-5).

Segundo Paula Falcão Argolo, a iconografia indiciária rompe com o silêncio das fontes escritas em relação à transgressão das leis suntuárias. Os vasos de contexto funerário exibem cenas de comportamentos proibidos pelas leis solonianas. Conclui a autora, concor- 
dando com Sarah Pomeroy, em seu livro Families in Classical and Helenistic Greece. Representation and realities, publicado em 1997, especialmente no que se refere às práticas funerárias, as legislações não eram facilmente aceitas pela sociedade e as mudanças não eram tão rápidas e nem os seus objetivos atingidos prontamente (Argolo 2001: 5).

Já no último quartel do século V. a.C., em torno de 415 a.C., ${ }^{17}$ quando Sófocles e Eurípides apresentam as suas peças, Ian Morris assegura que "os ricos tomam conta do que havia sido símbolo comunitário e a estruturação dos rituais de enterramento começa a se afrouxar, ao mesmo tempo em que ocorre um gasto maior neste tipo de atividade pela pólis e pelos individuos" (1992: 14).

Acreditamos que a fala de Electra abaixo possa fazer coro à nossa reflexão e que o poeta estivesse pensando nas leis suntuárias, nos moldes das referidas por Cícero, quando escreveu sua peça: Ah! Mãe desgraçada, capaz de todas as audácias, tu ousaste, em míseros funerais, sepultar um rei sem a presença dos cidadãos, um esposo sem gemidos nem lágrimas (vv. 429-431).

Finalmente, entre os gregos, a obrigação mais importante dos filhos era sepultar os pais. Dessa forma, a indignação de Electra e Orestes é completamente procedente se observarmos todo o aparato ritual que envolvia a morte - da preparação do corpo até o luto e o culto nas Genésias (cf. Florenzano 1996).

\subsection{Em Sófocles}

Na verdade, a evocação do lugar do drama tem mais a ver com o texto do que com a decoração. O homem antigo não vem ao teatro para ver, mas para escutar, e não é por acaso que a cenário se chama logeion. Vem-se ouvir uma palavra, não se surpreender com o espetáculo. É o ouvido não o olho que o poeta deseja seduzir. Como poderia ter sido de outra forma em um povo

(17) Não há consenso quanto às datas de representação das peças dos dois poetas. alimentado pelas recitações da Ilíada e da Odisseia, em um povo de contadores, não de narradores? (Bernand 1985: 19).

Concordamos em parte com o autor do trecho acima transcrito, Andrè Bernand, mas devemos estar atentos a um aspecto bastante importante, salientado por Aristóteles: o espetáculo é parte constitutiva da Tragédia (Poét. VI, 1450a 15). Ainda que seja o próprio Aristóteles quem diga que é possivel a Tragédia manifestar seus efeitos mesmo sem a representação e sem atores (Poét. VI, 1450b 20), provavelmente ele está pensando no prazer que proporciona a leitura da Tragédia, comum em seu tempo; ele não diz que o espetáculo não tem importância. Aristóteles, é bem verdade, estabelece prioridades quanto às partes constitutivas da Tragédia, dando maior relevância ao texto poético, declara que, antes do mais, é o cenógrafo e não o poeta o realizador do espetáculo (Poét. VI, 1450b 20). Mas conclui que a Tragédia é superior à Épica porque possui todos os seus elementos e "demais, o que não é pouco, a Melopéia e o espetáculo cênico, que acrescem a intensidade dos prazeres que lhes são próprios" (Poét. XXVI, 1462a 15). Assim, qualquer critica que se faça a Aristóteles, quanto à pequena atenção dada ao espetáculo, não se mostra de todo consistente; temos em mente, nesse instante, uma passagem de Oliver Taplin, no seu Appendix F, onde se lê: "No parágrafo 2, página 25, eu mantive que a Poética de Aristóteles era em parte responsável pela negligência do significado visual da Tragédia Grega" (Taplin 1989: 477).

Observemos o que acontece na Electra de Sófocles, segundo A. Bernand. "Em Sófocles, o espaço trágico, isto é, o lugar onde se passa o drama, se reduz a alguns elementos. O quadro é tão discreto que se poderia crer, à primeira vista, que Sófocles era insensivel ao mundo exterior (...) mas, em toda sua obra, é a ação trágica, não o espaço onde ela se desenrola, que o interessa" (1985: 101).

Orestes, acompanhado do seu preceptor e de seu fiel amigo, Pilade, chega à planície da Argólida "no raiar do dia". O preceptor mostra a Orestes os lugares que um dia ele foi obrigado 
a deixar: a floresta consagrada a Ínaco, a praça, o santuário de Hera e o palácio de Micenas.

É através de uma convenção cômoda que os atores são supostamente capazes de abraçar o conjunto da paisagem; mas eles estão na entrada da cidade, verossimilmente diante da famosa porta dos leões, rumo ao Noroeste, e a acrópole mascara os lugares evocados. À época de Sófocles, Micenas não existia mais e, se se pode dar crédito a Pausânias (II, XVI à XXIII), ela já estava em ruínas, então próximo ao que temos hoje. Nessas condições, pedir ao poeta uma preocupação com o realismo quase não tem sentido (Bernand 1985: 105).

A. Bernand acentua que "sem dúvida é vão querer encontrar no texto indicações topográficas sempre exatas: o objetivo primeiro do poeta não é ser realista" (Bernand 1985: 116). O autor cita Dreyfus ao analisar os espaços referenciados pelo Preceptor e mostra a impossibilidade de a visão abarcar, a um só tempo, os lugares mencionados. Para R. Dreyfus, obra publicada em 1967 - Tragiques Grecques: Eschyle, Sophocle - numa analogia a Paris, seria como se pudesse, de uma só vez, abarcar Notre-Dame, St-Denis e Versalhes. Logo, conclui A. Bernand, "trata-se de um cenário imaginário e verbal, mas emocionante porque mostra a ligação de Orestes com sua terra natal" (1985: 106).

A solução encontrada por Egisto e Clitemnestra para afastar Electra diverge em Sófocles e Euripedes. Em Sófocles, a heroina está sob severa vigilância dentro do palácio, não sendo permitida a sua saida sob risco de punição. Segundo Crisótemis, "Como tenho certeza de que nada fiz, nem tu [Electra], a quem punem se te afastas do paço" (p. 52; v. 910-913). Dai a surpresa de Clitemnestra quando a encontra fora do palácio: "vejam só quem passeia aqui sem peia, nem bem saiu Egisto, sempre avesso a que enlameies na sarjeta os seus!" (p. 38; w. 516520). Era o que Electra tentava fazer sempre que houvesse oportunidade, segundo depreendemos da fala de Crisótemis: "De novo dás vazão à ladainha na entrada do palácio?" (p. 32; wv. 328-
329). Reclusa, as possibilidades de Electra ocupar outros espaços eram praticamente nulas, salvo nos raros momentos em que fosse possivel a sua fuga; dai talvez se explique os poucos espaços de que lança mão o poeta, como acentuou Andrè Bernand acima, pois todo o tempo era na frente do palácio que ela se encontrava. Foi o máximo que Electra conseguiu alçar; nem ao túmulo ela podia ir, o que coube a sua irmã, Crisótemis, diferentemente da Electra de Ésquilo. Em Euripides, como veremos, a heroina é deliberadamente afastada do palácio através de outro ardil do padrasto.

\subsection{Em Eurípides}

Diferentemente de Ésquilo, para quem a cena de reconhecimento se dá no túmulo, e de Sófocles, que o faz na frente do palácio dos Atridas, Euripides é, no todo, o que mais se diferencia, ambientando o reconhecimento, e todo o resto da peça, no espaço rural. Electra reconhece Orestes em frente a sua casa por intermédio do velho pedagogo de Agamenão.

Vejamos sucintamente o cenário que o poeta nos apresenta. Orestes retorna à terra natal, dirige-se à zona fronteiriça, no espaço extra-muros, para encontrar a irmã e tramar o assassinato dos algozes do seu pai. Provavelmente ele ainda não soubesse, mas os muros limite entre a khóra e a ásty - e o interior da cidade eram fortemente vigiados pelos soldados de Egisto (p.104; vv. 615-617), o mesmo não acontecendo com o espaço rural, onde Orestes pode transitar livremente, apenas tendo cuidado para não ter a sua identidade descoberta por alguém que pudesse ligá-lo ao passado. Neste espaço, muito longe da cidade (ásty) (p.89; v. 246), vivem Electra e o seu marido numa casa muito simples, "no topo da grimpa ingreme" (p. 87; v. 210). Segundo a avaliação de Orestes, uma casa digna "de um poceiro ou de um vaqueiro" (p. 90; v. 252); para Electra,"uma maloca inóspita" (p. 92; v. 304), pouco guarnecida, que só tem o suficiente para alimentar os hóspedes no dia da sua chegada (p. 96; v. 424). Próxima à porta há uma estátua do deus Apolo, onde Electra se prostra e suplica, temendo o desco- 
nhecido que se aproxima; na verdade, Orestes. ${ }^{18}$ Electra cuida dos afazeres domésticos sem reclamar do pouco que o marido pode oferecerlhe. É numa das suas inúmeras tarefas como dona de casa - buscar água num riacho próximo com um vaso na cabeça - que encontra Orestes. O esposo deixa a casa bem cedo para cuidar dos animais e semear o campo. O campo está afastado da casa, não sabemos a que distância, mas o camponês provavelmente passava todo o dia fora retornando à noite. ${ }^{19}$

Não é só Electra que habita o espaço rural. O coro igualmente mora distante da ásty: "Eu também ardo por saber, pois moro a léguas da cidade [no texto grego, lê-se ásty] e desconheço os fatos tão nefastos que a devastam [no texto grego, devastam a pólis]" (p. 92; vv. 297-299). De igual modo, o Velho, a quem Electra solicita ao marido ir buscar, habita a khóra.

O camponês segue as margens do rio Tânao, no limite entre Argos e Esparta (p. 96; w. 410-411), para encontrar a casa do Velho. Este tem dificuldades em chegar ao casebre de Electra, pois precisa transpor um despenhadeiro (ou uma montanha) de dificil acesso, reclama do esforço sobre os joelhos e de como tem de se envergar para seguir adiante (p. 99; vv. 487-492), certamente uma área montanhosa e talvez pouco habitada. ${ }^{20}$ Nesse percurso, ele fez um pequeno desvio para libar à tumba de Agamenão. A tumba estava, de alguma forma, entre a sua casa e a de Electra logo, fora dos muros da cidade, diferentemente das duas

(18) "Oh Apolo Phebo! Eu caio a teus joelhos: salve-me da morte" (v. 221). Versos traduzidos a partir da versão francesa de Henri Berguin (Euripides 1913). Na nota de rodapé número 106, o tradutor explica: "Electra prostrouse diante da estátua de Apolo colocada perto da porta. [...] Essa estátua era colocada na porta das casas. Seu simbolo era um obelisco".

(19) André Leonardo Chevitarese (2000) realizou brilhante pesquisa, mostrando os vários tipos de assentamento possiveis no espaço rural. Tema sobre o qual nos debruçaremos em outra oportunidade.

(20) Para Andrè Bernand, a "paisagem de águas correntes que condiz, é verdade, com o vale verdejante do Eridanos e da planície costeira, responde mal aos despenhadeiros rudes e secos da Argólida; ela está de acordo com a visão embelezada da cidade tal como a sustentam os refugiados [das tragédias]" (1985: 42). outras peças, em que o túmulo parece estar próximo ao palácio, sobretudo em Ésquilo. Foi no túmulo que Orestes deixou o cacho de cabelos, ali onde o velho prestou homenagem e que Egisto, inversamente, ultrajava, crivando-o de pedras e escarrando sobre ele (p. 93; vv. 326329). Provavelmente sacasse as pedras do próprio terreno do túmulo, pois Electra afirma que ele era pedregulhoso (p. 100; v. 534). Segundo Maria Beatriz Borba Florenzano, pelos registros arqueológicos disponiveis constata-se que, no território ático (o poeta pode fazer alusão a algo comum em sua região), era costumeiro enterrar os mortos tanto dentro dos limites da cidade quanto além dos muros. $\mathrm{Na}$ época clássica, entretanto, enterrava-se especialmente do lado externo dos muros. Ademais, os cemitérios encontravam-se próximos às casas das familias dos mortos para os cuidados devidos (Florenzano 1996: 66-67). Na Helena, de Euripides, o túmulo de Proteu foi erigido pelo filho propositalmente à entrada do palácio para tê-lo sempre próximo (Euripides Helena: vv. 1165-1167).

Egisto estava na hinterlândia de Argos [no texto grego, no campo, agrós], acompanhado de seus escravos, para preparar um rito às ninfas (p.104; v. 623-625). Clitemnestra iria participar desse ritual, mas só seguiria para o local sagrado algum tempo depois (p. 105; vv. 641643). ${ }^{21}$ Eles evitavam ser vistos juntos, "a urbe [no texto grego, pólis] a vê com menosprezo" (p.105; v. 644). Contudo, Clitemnestra é atraida para a casa de Electra sob o pretexto de realizar o sacrifício do décimo dia de um suposto neto. Na emboscada, os filhos cometem o matricidio.

O Velho guia Orestes até o local sagrado, onde Egisto é visto no jardim, colhendo ramos

(21) $\bigcirc$ texto não deixa claro como era exatamente esse local sagrado, a referência é ao altar. N. Marinatos faz alusão à afirmação de Christiane Sourvinou-Inwood (1993: 1-13), de que, "em Homero, o espaço sagrado era definido por um altar" (Marinatos 1993: 2). Na verdade, não sabemos se o poeta tinha em mente um templo, um santuário ou apenas o altar. Não havia uma uniformidade em relação aos espaços sagrados. Existiam altares espalhados por toda a Grécia, às vezes em um templo ou em um santuário. 
de mirto. Egisto recebe hospitaleiramente aqueles viajantes: na verdade, o vingador, Orestes, e os seus companheiros. Solicita aos servos banhos para os convidados antes de se aproximarem do altar, o que é dispensado com a justificativa de os hóspedes terem se banhado recentemente num riacho de água limpida (p. 111-112; vv. 785-794). Próximo ao altar, um local sagrado e público, Egisto é assassinado e o seu corpo é levado para Electra. Os altares e demais espaços sagrados eram locais de grande respeito e serviam, muitas vezes, de asyla, ou lugares de refúgio, por isso estranhamos a solução de Eurípides para o assassinato de Egisto ali mesmo. Os dois homicidios ocorrem num contexto religioso: o sacrifício (não pretendemos desenvolver esse tópico).

É interessante pensar na solução apresentada pelo poeta, na liberdade com que transitou pelo mito sem, no entanto, mudar sua essência. Em nenhum momento o espaço urbano serve de cenário; ele é apenas evocado quando se faz menção ao palácio dos Atridas. A casa de Electra, a do Velho, a do Coro, todas estão no espaço rural. O local onde Egisto sacrifica às ninfas também é no espaço extra-urbano, e é para casa de Electra que Clitemnestra é atraida. Electra e Orestes não ultrapassam os muros, não vão ao palácio, diferentemente do que ocorreu nos textos de Ésquilo e Sófocles, em que Electra habita o palácio paterno e os assassinatos são cometidos em seu interior, num espaço privativo da nobreza. É bem verdade que Egisto, em Sófocles, está no campo, mas a esposa manda chamá-lo ao palácio para dar a notícia da morte de Orestes. A relação cidade-campo não parece distante. Os reis costumavam visitar o espaço rural e, por vezes, realizar ali os seus rituais, como visto em outras peças, como no Édipo em Colono, de Sófocles: Teseu está no demo de Colono, fazendo um sacrifício ao protetor do lugar, Poseidon (wv. 1014-1017). Esses espaços sagrados na região de fronteira eram provavelmente a forma encontrada para integrar o território ao restante da cidade e, de alguma forma, também prestigiá-lo. Assim, o ritual se reveste de certa importância para contar com a presença da rainha. Clitemnestra, mesmo temendo o que os outros iriam dizer, apareceria em público, ao lado do marido, para os sacrificios.
Sabemos que o desejo de Egisto, ao dar Electra em matrimônio ao camponês, era enfraquecer a sua prole e desarticulá-la do seu status de cidadã, rebaixando-a da sua condição de princesa e alijando-a do centro de poder. Sob este ângulo, poderiamos pensar que a khóra fosse um espaço de exclusão - para lá que Electra é enviada. O Velho também mora na khóra. São ambos indesejáveis na ásty pelos seus governantes, pois eles estão fortemente vinculados a um passado do qual Egisto e Clitemnestra desejam se libertar. Um olhar mais acurado, todavia, pode fazer cair por terra esse espaço como ambiente de exclusão: o Coro de jovens argivas, filhas de cidadãos, habita esse espaço e não nos parece que se trate de jovens de baixa extração social, pois tão logo Electra expõe as suas parcas condições materiais quando convidada para participar do cortejo ao templo de Hera, as moças prontamente ofertam-lhe trajes para que ela se ponha adequadamente ( $\mathrm{p}$. 87; vv. 190-193). Talvez, para pensar o espaço na Electra de Euripides, devamos amadurecer um aspecto que nos chamou a atenção na leitura do projeto desenvolvido atualmente pelo labeca: através de estudos arqueológicos, é possivel saber que no decorrer da época clássica e da helenística ocorreu o auge da ocupação rural em todo mundo grego. ${ }^{22}$ É a tarefa a que nos lançaremos em um futuro próximo.

\section{Agradecimentos}

Muitas das ideias que tentamos desenvolver aqui foram resultados das estimulantes aulas ministradas pela professora Adriane da Silva Duarte (PPGLC/FFLCH/USP) e fruto do contato sempre rico e proveitoso com a professora Maria Beatriz Borba Florenzano, nossa orientadora; por óbvio, as imperfeições ou as deficiências são de minha inteira responsabilidade. Agradecemos ainda ao CNPq por financiar o nosso trabalho de pesquisa.

(22) Projeto intitulado "A Organização da Khóra: a cidade grega diante de sua hinterlândia”, 2010; cedido gentilmente pela professora Maria Beatriz Borba Florenzano. 
RIBEIRO, M.C.L. Electra and Orestes: recognition and space in Greek tragedy. Revista do Museu de Arqueologia e Etnologia, São Paulo, 20: 251-276, 2010.

Abstract: This text aims initially to raise some aspects related to the recognition (anagnórisis) between Electra and Orestes based on Aristotle's Poetics; in a second moment, to reflect on the space where such scenes take place. The recognition scene between Electra and Orestes is provided to us by the three tragicians whose plays came completed to us: Aeschylus (Choephoroi), Sophocles (Electra) and the homonymous tragedy by Euripides (Electra).

Keywords: Recognition scenes - Space - Greek tragedy - Electra.

\section{Referências bibliográficas}

ALCOCK, S.E.

1991 Tomb Cult and the Post-Classical Polis. American Journal of Archaeology, 95: 447-467.

ANTONACCIO, C.M.

1999 Colonization and the Origins of Hero Cult. Acta Instituti Atheniensis Regni Sueciae. Series In 8, XVI, Stockholm: 109. 121.

ARGOLO, P.F.

2001 Ritos Funerários e Leis Suntuárias da Polis Ateniense. Disponivel em www.gaialhia.kit.net/artigos/paula2001; acesso Junho 2010.

ARISTÓFANES

1992 The Acharnian, The Knights, The Clouds, The Wasps. Trad. Benjamin Bickley Rogers. Cambridge, Massachusetts, London: Harvard University Press.

\section{ARISTÓTELES}

1993 Poética. Tradução de Eudoro de Souza. São Paulo: Ars Poética.

BELFIORE, E.S.

1992 Tragic Pleasures Aristotle on Plot and Emotion. Princeton: Princeton University Press.

BERNAND, A.

1985 La carte du tragique. La géographie dans la tragédie grecque. Paris: Centre National de La Recherche Scientifique.

BRANDÃO, J.L.

2001 Electra no Espelho. In: Brassete, M.F. (Org.) Máscaras, Vozes e Gestos: nos caminhos do teatro clássico. Aveiro, Universidade de Aveiro: 115-129.
CHALKIA, I.

1986 Lieux et espace dans la tragédie d'Euripide. Essai d'analyse sócio-culturelle. Thessaloniki: Ath. Altintzis.

CHEVITARESE, A.L.

2000 Espaço Rural da Pólis Grega. Rio de Janeiro: Fábrica de Livros.

DIAS, C.K.B.C.

2009 Colonização grega e contexto cultural na Magna Grécia. O testemunho dos vasos lucânicos. In AEDOS. Revista do Corpo Discente da PPG História-UFRGS. N. 5; v. 2. Disponivel em http://seer.ufrgs.br/ index.php/aedos/article/viewFile/ 10267/7315; acesso junho 2010 .

DUARTE, A.S

2005 Cenas de Reconhecimento na Comédia Aristofânica. In: Fachin, L;; Dezotti, M.C.C. (Orgs.) Em Cena O Teatro. Araraquara; São Paulo: Cultura Acadêmica; Araraquara: Laboratório Editorial UNESP: 157-175.

ÉSQUILO

2008 Oresteia (Agamenon, Coéforas, Eumênides). Trad. Manuel de Oliveira Pulquério Lisboa: Edições Setenta.

\section{EURÍPIDES}

1913 Electre. Trad. francesa de Henri Berguin. Murray, G. (Ed.) Ed. bilingüe. Disponivel em http://remacle.org/bloodwolf/tragediens/ euripide/electre.htm; acesso Junho 2010.

1913 Euripidis Fabulae. Ed. Gilbert Murray; vol. 2. Oxford: Clarendon Press. Disponivel em http://www.perseus.tufts.edu/hopper/ text?doc=Perseus\%3Atext\%3A1999.01.0095 \%3Acard\%3D262; acesso junho 2010. 
1913 Euripidis Fabulae. Ed. Gilbert Murray, vol. 3. Oxford: Clarendon Press. Disponivel em http://www.perseus.tufts.edu/ hopper/text?doc $=$ Perseus $\% 3$ Atext $\%$ 3A1999.01.0099\%3Acard\%3D1165; acesso Junho 2010.

1938 Electra. Trad. E.P. Coleridge. In: W.J. Oates; E. O’Neill Jr. (Eds.) The Complete Greek Drama. New York: Random House; vol. 2. Disponivel em: http://www.perseus. tufts.edu/hopper/text?doc $=$ Perseus\%3Atext \%3A1999.01.0096\%3Acard\%3D774; acesso junho 2010.

FITTON- BROWN, A.D.

1961 The Recognition-Scene in Choephori. Rerue des Études Grecques, LXXIVI: 363-370.

FLORENZANO, M.B.B.

1996 Nascer, Viver e Morrer na Grécia Antiga. São Paulo: Atual.

HOMERO

2009 Ilíada. Trad. Frederico Lourenço. Lisboa: Biblioteca Editores Independentes.

JEBB, R.

1894 The Electra of Sophocles. Ed., introd. e notas de R. Jebb. Cambridge: Cambridge University Press. Disponivel em http:// www.perseus.tufts.edu/hopper/text?doc= Perseus\%3atext\%3a1999.01.0187; acesso Junho 2010.

JOUANNA, J.

1997 Notes sur la Scène de la Reconnaissance dans les Choéphores d' Eschyle (vv. 205-211) e sa parodie dans l'Electre d'Euripide (vv.532-537). Cahier Gita, 10: 69-85.

LAWRENCE, D.L.; LOW, S.M.

1990 The built Environment and Spatial Form. Annual Review of Antropology, 19: 453-505. Disponivel em http:// www.jstor.org; acesso 25/05/2009.

MALKIN, I.

1987 Cap. VI: Os fundadores e seu culto. In: Religion and Colonization in Ancient Greece. Leiden: Brill Archive: 204-240 (Studies in Greek and Roman Religion; 3). [Trad. Cibele E. V. Aldrovandi; rev. M. Beatriz B. Florenzano; colaboração Christiane T. Custodio; disponivel em www.mae.usp. br/labeca; acesso junho 2010]

MARINATOS, N.

1993 What Were Greek Sanctuaires? A synthesis. In: Marinatos, N.; Hagg, R. (Eds.) Greek Sanctuaries. New Approaches. Londres, Routledge: 228-233. [Trad. de E.F.V. Hirata; disponivel em www.mae.usp. br/labeca; acesso Junho 2010]

MEZZADRI, B.

1997 Euripide à contre-pied (à propos des Choèphores 205-211 et de l'Electre d'Euripide 532-537. Cahier GITA, 10: 89-105

MORRIS, I.

1992 Death ritual and social structure in Classical Antiquity. Cambridge University Press. [Trad. de M.B.B. Florenzano disponivel em www.mae.usp.br/labeca; acesso junho 2010]

OLIVEIRA, F.R.

2006 As anagnoriseis de Electra. In Santos, M. M. (Org.) 1 Simpósio de Estudos Clássicos da USP. São Paulo: Humanitas: 133-143

PUCCI, P.

1967 Euripides heautontimoroumenos. Transactions and Proceedings of the American Philological Association, 98: 365-371.

RAPOPORT, A.

1978 Aspectos Humanos de La forma urbana. Barcelona: Gustavo Gili.

1982 The meaning of built environment: a nonverbal communication approach. Arizona: University of Arizona Press.

RONNET, G.

1975 L'ironie d'Euripide dans l'Électre (vers 513 a 546). Revue des Etudes Grecques, LXXXVIII: 419-423.

SÓFOCLES

2001 A Trilogia Tebana: Édipo Rei, Édipo em Colono, Antígona. Trad. Mário da Gama Kury. São Paulo: Jorge Zahar.

SOLMSEN, F.

1967 Electra and Orestes. Three recognitions in Greek tragedy. Amsterdam: N.V. NoordHollandische Uitgevers Maatschappij.

SOURVINOU-INWOOD, C.

1993 Early sanctuaries, the eighth century and ritual space. Fragments of a discourse. In: Marinatos, N.; Hagg, R. (Eds.) Greek Sanctuaries. New Approaches. Londres, Routledge: 1-13.

TAPLIN, O.

1989 The Stagecraft of Aeschylus. The Dramatic Use of Exits and Entrances in Greek Tragedy. Oxford: Oxford University Press.

TUCÍDIDES

1987 História da Guerra do Peloponeso. 3. ed. Trad. do grego, introd. e notas de Mário 
da Gama Kury. Brasilia: Editora Universidade de Brasilia.

VERNANT, J.P.

2002 Entre Mito e Política. São Paulo: Editora da Universidade de São Paulo.

2006 Mito e Religião na Grécia Antiga. São Paulo: WMF Martins Fontes.
VIEIRA, V.

2009 Sófocles/Euripides. Electra(s). Trad. Trajano Vieira. São Paulo: Ateliê Editorial WILES, D.

1988 The Staging of the recognition scene in the Choephoroi. The Classical Quarterly, 38 (1): $82-85$.

Recebido para publicação em 10 de novembro de 2010. 